UNIVERSIDADE DE SÃO PAULO

FACULDADE DE FILOSOFIA, LETRAS E CIÊNCIAS HUMANAS

DEPARTAMENTO DE LETRAS MODERNAS

PROGRAMA DE PÓS-GRADUAÇÃO EM LÍNGUA E LITERATURA ITALIANA

MARCELO EDUARDO REDOSCHI

O autor "florentino" da literatura suíça em língua italiana: Francesco Chiesa 
MARCELO EDUARDO REDOSCHI

\section{O autor "florentino" da literatura suíça em língua italiana: Francesco Chiesa}

Dissertação apresentada à Faculdade de Filosofia, Letras e Ciências Humanas da Universidade de São Paulo para a obtenção do título de Mestre em Letras

Área de concentração: Língua e Literatura Italiana

Orientadora: Profa. Dra. Lucia Wataghin

São Paulo

2008 


\section{FOLHA DE APROVAÇÃO}

Marcelo Eduardo Redoschi

O autor "florentino" da literatura suíça em língua italiana: Francesco Chiesa

Dissertação apresentada à Faculdade de Filosofia, Letras e Ciências Humanas da Universidade de São Paulo para a obtenção do título de Mestre em Letras.

Área de concentração: Língua e Literatura Italiana.

Aprovado em:

Banca Examinadora

Prof. Dr.

Instituição:

Assinatura:

Prof. Dr.

Instituição:

Assinatura:

Prof. Dr.

Instituição:

Assinatura: 
DEDICATÓRIA 


\section{AGRADECIMENTOS}

À minha eficientíssima orientadora, professora Lucia, por ter me habilmente guiado no alpinismo literário que é se estudar os Svizzeri, e em especial, Francesco Chiesa.

Aos amigos Aude e Alain pelo empenho no envio desde a Suíça dos livros fundamentais desta pesquisa, Tempo di marzo e Io e i miei.

À Silvia Garcia, amiga dos dicionários, verbiários e gramáticas alemãs todas.

Ao poeta Alberto Nessi pela atenção e cordialidade durante sua palestra sobre a Suíça italiana por ocasião de sua visita à São Paulo em 2005.

Ao professor Pedro pelas aulas especialíssimas sobre o Orlando Furioso.

À profa. Vilma Katinsky e prof. Julio Pimentel pelas recomendações apresentadas no exame de qualificação.

Ao professor Francesco Guardiani por insistir na leitura de Plinio Martini.

À Maria Celia Fantin, a contista mais italiana de Curitiba.

Uma lembrança à Concetta Thibideau, minha maestra ítalo-americana. 


\section{EPÍGRAFE}

1 'Arno balsamo fino

le mura di Firenze inargentate,

le rughe di cristallo lastricate,

fortezze alt' e merlate,

mio fedel fosse ciaschedun latino,

il mondo in pace, securo 'l camino,

no mi noccia vicino,

e l'aria temperata verno e state

(Lapo Gianni, Rime, XV) 


\section{RESUMO}

REDOSCHI, M.E. O autor "florentino" da literatura suíça em língua italiana: Francesco Chiesa. 2008. 90 pag. Dissertação (mestrado) - Faculdade de Filosofia Letras e Ciências Humanas, Universidade de São Paulo, São Paulo, 2008.

A Suíça é um país situado no centro da Europa ocidental e conta com quatro idiomas oficiais: o alemão, o francês, o italiano e o romanche. A Confederação Helvética possui vinte e seis unidades administrativas, denominadas Cantões, formados ao longo da história, que contam com um alto grau de autonomia.

O idioma de Dante está presente como língua materna de boa parte da população do Cantão de Ticino e de quatro vales alpinos no vizinho Cantão Grisões, onde divide espaço com o alemão e o romanche. É apresentado o contexto formativo do italiano falado na região, que se padronizou em torno da norma toscana a partir do Séc XVI, graças à qualidade das escolas mantidas por religiosos como São Carlos Borromeo. Eram utilizadas as gramáticas e métodos mais modernos disponíveis na época.

Nesta encruzilhada de civilizações, de área habitada equivalente à cidade de São Paulo e $\mathrm{ABCD}$, surgiu Francesco Chiesa. Foi o primeiro escritor suíço a efetivamente a desbravar o árduo mercado editorial italiano, colocando assim o nome de sua região definitivamente nos manuais de língua e literatura.

À sua numerosa produção em poesia e prosa, soma-se a longeva biografia (1871-1973). Destacam-se suas atividades como professor de língua, historia da arte, jornalista e defensor do patrimônio artístico e cultural de origem lombarda de sua terra.

Em 1925 seria publicado Tempo di marzo, que se tornaria sua obra mais conhecida no exterior. Um retrato da sociedade agrária do Ticino do início do novecentos, o romance é uma transposição lírica da realidade histórica da região. À medida que o garoto Nino transcorre o final de sua infância, passamos a conhecer melhor a geografia, usos e costumes do Ticino de antigamente. Por sua escrita límpida, fluída, quase "manzoniana" o romance foi discutido e ensinado nas escolas do norte da Itália, como exemplo de redação em italiano padrão.

Completado em 1943, Io e i miei, é uma obra 'moderna', dentro da estética Chiesiana. Lançado em pleno período da guerra, fatores logísticos impediram que o livro tivesse a merecida repercussão. Uma espécie de híbrido de conto e romance, lá são narrados os conflitos internos de uma família de viúvos recasados, da filha Serafina e do filho Manlio. São evidenciados sobretudo os dramas do pai. Um pessimismo e uma resignação lânguida, em contraste à jovialidade e alegria de Tempo di marzo, permeiam a narrativa. $\mathrm{O}$ registro melancólico dos vilarejos em decadência é comparado à extratos de Il fondo del sacco, escrito pelo romancista grisonês de temática realista Plinio Martini, cerca de trinta anos mais tarde.

Francesco Chiesa foi o primeiro e o mais "florentino" dos escritores suíços de expressão italiana. 


\begin{abstract}
REDOSCHI, M.E. The "florentine" author of Switzerland's literature in italian: Francesco Chiesa. 2008. 90 pag. Master's Thesis - Faculty of Filosofy, Letters and Human Sciences (FFLCH), Universidade de São Paulo, São Paulo, 2008.
\end{abstract}

Switzerland is a country located at the center of western Europe with four official languages: German, French, Italian and Romansch. The Helvetian Confederation has twenty-six highly autonomous administrative units, called Cantons, formed throughout history.

Dante's language is present as the mother tongue of the bulk of Canton Ticino's population as well in four alpine valleys on the nearby Canton Grisons. There it shares space with SwissGerman and Romansch. The background for the formation of the Italian spoken in the region, which had standardized around tuscan rules from the sixteenth century - thanks to the quality of schools maintained by clerics such as Saint Charles Borromeo - is presented. The most modern grammars and teaching methods available at the time were used.

At this crossroads of civilizations, with an inhabited area equivalent to the city of São Paulo and a few nearby suburbs, appeared Francesco Chiesa. He was the first Swiss author to effectively brave the italian book market, thus inscribing his region's name forever on the Italian language and literature textbooks.

Added to his prolific production in prose and verse, is his longevous biography (1871-1973). Worthy of note are his activities as professor of italian, art history, journalist and supporter of his land's lombardic cultural and artistic heritage.

In 1925 would be published Tempo di marzo, which would become his best known work abroad. A portrait of agrarian Ticino society at the early nineteen-hundreds, the romance is a lyric transposition of the region's historical realities. As the boy Nino moves toward the end of his childhood, we get to experience the geography, customs and traditions of yesteryear Ticino. By virtue of his clear, fluid, almost "manzonian" writing, the novel was discussed and taught at Northern Italy schools. It was used as a model in italian composition classes.

Finished in 1943, Io e i miei, is a 'modern' work, within Chiesa's style. Released right in the middle of wartime, logistical factors prevented the book from having a much deserved accolade. A sort of hybrid between a short story and a novel, it narrates the internal conflicts of a family of remarried widowers, the daughter Serafina and the son Manlio. In evidence are the father's issues. A pessimistic tone, of quiet languishing and resignation, in contrast to the youthfulness and joy of Tempo di marzo strides the narrative. The melancholic account of deserted, decadent villages is compared to extracts of Il fondo del sacco, written third years later by the Grison native Plinio Martini, which had embraced realism themes.

Francesco Chiesa was the first and most "Florentine" of Italian speaking Swiss authors. 


\section{LISTA DE ILUSTRAÇÕES}

Figura 1 - Vilarejos 'de cima' e 'de baixo' da montanha (vista do Lago Ceresio). .19

Figura 2 - Xadrez gigante de rua em Lugano .32

Figura 3 - Io e i miei, prefácio da Editora Cantonetto 54

Figura 4 - Representação da batalha de Morgarten. .72

Figura 5 - Mapa lingüístico dos Grisões (por município). .75

Figura 6 - Mapa da estrutura político-administrativa suíça.. .77

Figura 7 - Ilustração dos estatutos da cidade de Carona (1482). .84 


\section{LISTA DE TABELAS}

Tabela 1 - Quadro sintético da produção Chiesiana.....................................................30

Tabela 2 - Vocábulos presentes em textos de Brissago................................................83

Tabela 3 - Línguas da vida profissional no cantão de Ticino .....................................86 


\section{SUMÁRIO}

\section{PREFÁCIO}

APRESENTAÇÃO

1 "QUESTIONE DELLA LINGUA"

1.1 Formação de um italiano regional (séculos XV-XVIII)

1.2 O italiano oitocentesco

1.3 Início do Novecentos

1.4 O "florentinismo" de Chiesa em defesa da língua

2 MEMÓRIA CULTURAL EM TEMPO DI MARZO

2.1 Referências à agricultura lombarda medieval

2.2 Terra de camponeses rústicos

2.3 Deslocamentos e imigração

2.4 Referências às instituições locais

3.1 Contraste com Tempo di marzo

3.2 Loucura, personificação e melancolia

3.3 Personagens espectrais

3.4 Diálogos com Il fondo del sacco

3.5 O drama de Cam

3.6 Hoje fiz um inimigo

3.7 Coisas que acontecem 


\section{PREFÁCIO}

Meu contato inicial com o universo da Suíça italiana ocorreu em meados dos anos noventa do século passado, quando cursava a graduação. Durante umas breves férias, tive a oportunidade de visitar os grisões. A lembrança daquela paisagem pitoresca de lagos e montanhas aficou impregnada na memória. Foi uma experiência singular conversar uma parte em italiano, outra em inglês, de modo a tentar entender o romanche do dono da hospedaria, vizinha aos trilhos do trem.

De fato, conforme as pessoas entravam nos vagões da chamada ferrovia rética, se cumprimentavam, ora em dialeto suíço-alemão, ora no que julgava ser romanche, ora em italiano, dependendo do vale e altura da serra onde nos encontrávamos. Finalmente, chegamos a Poschiavo, última parada antes da fronteira. Em nossos padrões brasileiros, esta cidade dos grisões de língua italiana é uma vila de casinhas do tamanho de um bairro de Campos do Jordão. Quando lá estive, o trem fazia vez de bondinho urbano e serpenteava as estreitas ruas. Acenavam as vovós aos meninos que alegres e despreocupados com o mundo exterior, jogavam bola na rua e conheciam os maquinistas dos trens todos.

Meu itinerário, por assim dizer, da Suíça italiana só se completaria anos mais tarde, durante uma visita a Lugano, principal destino turístico da região e importante centro cultural com museus, bibliotecas e a USI (Università della Svizzera Italiana), única instituição no mundo, além das fronteiras da península, a ministrar cursos superiores primordialmente em italiano. 
Me recordo que no primeiro ou segundo dia em Lugano, escutei uma transmissão radiofônica local. Às vezes quando estou em viagem a lugares "diferentes" (ou seja que ainda não conheço) tenho o costume de sintonizar as rádios, de modo a escutar o idioma.

Curiosamente, na hora passava um programa educativo, uma espécie de reprise de uma transmissão chamada "Radioscuola", que soubera pelo gerente do hotel que os estudantes de colegial lá todos escutavam, em período letivo. Ou costumavam escutar, quando eram garotos. Pelo que me recordo a edição daquele dia resenhava um dos autores tradicionais da "Svizzera italiana", o já falecido Giuseppe Zoppi.

Zoppi, conforme descobri posteriormente, foi um conhecido autor e professor universitário suíço durante as primeiras décadas do XX. Por uma daquelas coincidências do destino foi também o primeiro a escrever academicamente sobre Francesco Chiesa. Seu trabalho de conclusão de curso na universidade de Friburgo versou sobre a poesia chiesiana. Em termos de sua própria produção, Zoppi também é bastante conhecido por Il libro dell'alpe de 1922, que encantou gerações inteiras de crianças do cantão de Ticino ${ }^{1}$.

Mais tarde, já no Brasil, tivera a curiosidade aguçada a propósito deste tema da Suíça italiana. Após pesquisar mais a fundo, descobri que haviam sido disponibilizadas diversas transmissões educativas e resenhas literárias de seus grandes autores na Internet. O fato deste material historiográfico e de crítica literária de alta qualidade, haver sido digitalizado por um órgão oficial e confiável, auxiliou a realização deste trabalho haja visto as enormes distâncias históricas, geográficas e culturais que separam a nossa "Suíça brasileira" daquela "italiana".

\footnotetext{
${ }^{1}$ cfr. (BONALUMI, MARTIRONI, MENGALDO; 1997, p. 9)
} 


\section{APRESENTAÇÃO}

Nascido em Sagno, vilarejo de montanha próximo à comuna de Mendrisio, no extremo sul da Suíça, vizinho à fronteira italiana, Francesco Chiesa cursou os estudos primários e secundários no cantão de Ticino. De família de profissionais liberais, seguindo o costume da região (de se enviarem aos filhos a universidades de língua italiana), foi continuar seus estudos na península, onde se formaria advogado. Já na Universidade de Pavia (cidade por onde passa o rio que dá nome a seu cantão), o jovem suíço despontava seu talento literário com participações nas atividades do grêmio estudantil helvético (AGLIATI, 1976, p. 12).

Seu primeiro livro foi publicado em 1897, uma coletânea de poesias em estilo oitocentesco (carducciano). Preludio rendeu-lhe o primeiro prêmio no concurso oficial de poesia do cantão de Ticino. Com isso, veio o convite que mudaria por completo sua vida e faria com que entrasse na história da literatura italiana. Comenta o escritor suíço Mario Agliati, especialista na obra de Chiesa, que lhe foi posto o desafio, prontamente aceito, de lecionar italiano no liceu de Lugano (AGLIATI, 1976, p. 20).

Si sa poi che, anche grazie alla fama ormai acquisita di poeta, adesso consacrata da Preludio (del quale s'ebbero lusinghiere recensioni in Italia e anche oltr'alpe), il Chiesa venne chiamato, nel novembre del 1897, a coprir la cattedra di italiano nello stesso liceo che lo aveva visto sette anni prima allievo, e divenne così, senza che lui ci avesse pensato mai, professore. Il che comporterà l'inizio di un gravoso impegno, ché il Chiesa si butterà con grande passione nell'insegnamento, non risparmiando nessun sacrificio per conoscere a pieno i ferri del suo nuovo mestiere, per impossessarsi a fondo della storia letteraria e, subito dopo, anche della storia dell'arte, di cui di lì a poco (1898 o 1899) del pari assumerà la cattedra, sia pure per un insegnamento, in que' primi anni, soltanto facoltativo.

A Suíça ganhava assim, por um daqueles acidentes, ou talvez predestinações da história, seu primeiro grande literato de expressão italiana. 
Nascido em 1871, Francesco Chiesa permaneceu ativo no cenário literário por praticamente toda a vida. Sua numerosa produção em poesia e prosa rendeu-lhe prêmios e reconhecimentos de ambos os lados da fronteira (CALGARI, 1968, p. 319). Em 1925 foi publicado Tempo di marzo, que se tornaria seu maior sucesso de público. Quanto a seu estilo, conforme acenam os estudiosos e sobre o qual iremos discorrer mais à frente neste trabalho, é florentino, quase escolástico por vezes.

A escritura de Chiesa em Tempo di marzo é límpida, fluida, quase manzoniana, se podemos usar o termo. Por vários anos, Tempo di marzo foi empregado nos ginásios da Suíça italiana e da vizinha Lombardia como material didático, de apoio às aulas. Um exemplo de italiano quase que construído, utilizando a norma culta toscana.

Dificuldades de caráter logístico fizeram com que a segunda obra a ser analisada neste trabalho fosse Io e $i$ miei, um romance de sua fase biográfica posterior, quando já tinha setenta e três anos. Escrito em plena Segunda Guerra Mundial, Io e i miei é uma espécie de escritura de "vanguarda", com características modernas, dentro da obra chiesiana, que é tida como formalista. Essa expressividade mais próxima ao realismo foi uma grande surpresa, pois brindou-nos com possibilidades de confronto. Para realçar essa característica contemporânea e a atemporalidade da obra, comparare-mo-la com extratos de uma obra da moderna narrativa da Suíça italiana, Il fondo del sacco, do grisonês Plinio Martini.

Observamos que tais análises serão feitas com o propósito maior e norteador de atingir uma compreensão melhor desses fenômenos culturais da história da Suíça italiana (cantão de Ticino e áreas do cantão dos Grisões), cuja formação será apresentada no primeiro capítulo, de modo a contextualizar os trabalhos.

Terra com uma extensão habitável comparável à das cidades de São Paulo e do ABCD paulista, a população italófona da Suíça é equivalente à de um bairro da capital paulista (são 
cerca de trezentas e trinta mil pessoas que têm como língua materna o idioma de Dante). Frisamos que a literatura na região, entendida em seu sentido amplo de "fazer criativo", é um fenômeno sobretudo do século XX.

Entre os escritores suíços de expressão italiana, Francesco Chiesa é o primeiro a publicar. Seu talento literário e presença seriam marcantes na vida cultural de sua terra, sobretudo na primeira metade do XX.

Procuramos, portanto, oferecer uma amostra do inegável talento literário de Chiesa, que, com aptidão, fluidez e segurança ao colocar os pontos nos 'is', descreve os movimentos da natureza e das pessoas de sua terra natal. Mesmo sem ter pupilos literários, fez o mais importante: colocou o Ticino definitivamente no mapa da produção em língua italiana.

Afirma Orelli (CAMARTIN et al, 1996, p. 139): "No campo das belas letras é provavelmente suficiente dizer que a literatura na Suíça de idioma italiano começou com Francesco Chiesa (1871-1973), em outras palavras no inicio do século XX”.

Lembramos, contudo, antes de concluir esta introdução, que a Suíça é um país extremamente complexo em sua formação lingüística e composição cultural, que abriga quatro povos de origens distintas: alemã, francesa, italiana e romanche. Consiste portanto, em verdadeiro desafio o estudo de um autor que pertença a essas tradições.

A propósito da necessidade de se discorrer sobre o particular contexto formativo da região de modo a melhor se compreender a produção e os autores da Suíça de expressão italiana, afirmou Mangan (1999, p. iii):

Poiché il contesto geografico, sociale e politico in cui nasce e si evolve la letteratura di cui ci si vuole occupare influisce molto spesso sugli esiti della stessa, si è deciso di soffermarci ampiamente su di esso prima di entrare nel merito dell'analisi che ci proponiamo. L'importanza di tale contesto ci ha anche suggerito il taglio da dare al nostro lavoro. 
Além de apresentar trechos do autor suíço mais florentino do século XX, uma das minhas expectativas pessoais em relação a este trabalho é despertar no público brasileiro o interesse pela leitura da produção da Svizzera italiana, na plenitude de seus aspectos literários e culturais (geográficos, históricos e lingüísticos), que se inter-relacionam² (vide Apêndices).

Acerca das descobertas arqueológicas feitas no cantão de Ticino e da origem desse povo, afirma o próprio Francesco Chiesa (1928, p. 7) em um livro onde catalogou minuciosamente o patrimônio artístico e cultural de sua terra, possivelmente de origem etrusca ou lígure, civilizações pré-romanas. É mencionada a figura de Caronte, que aparece na Eneida de Virgílio e na Divina commedia de Dante, duas obras basilares da cultura latina e italiana.

In quasi tutte le regioni del Cantone Ticino furono scoperte e si scoprono tombe sotterranee rozzamente costrutte, per lo più, con ciottoli e lastroni di pietra, nelle quali si trovano, insieme con qualche ossame, vasi di terracotta di bronzo, fibbie e spille pure di bronzo, collane di ambre o di bronzo, collane di ambre o di vetro colorato, altri oggetti di bronzo, di vetro, di ferro. Era usanza quasi generale presso i popoli antichi di seppellire i loro morti mettendo nelle tombe alcuni oggetti della vita familiare. I Romani vi mettevano anche qualche moneta, con cui (secondo un'antica credenza) il morto avrebbe potuto pagare l'obolo al nocchiero Caronte per ottenere d'esser tragittato nei regni della seconda vita. Ora, dall'osservazione di quegli oggetti (trovati in grande copia principalmente nei dintorni di Bellinzona: a Giubiasco, a Pianezzo, ad Arbedo, a Gudo) gli scienziati sono venuti alla conclusione sicura che il nostro paese fu abitato da popoli antichissimi, dei quali non è però facile dire con sicurezza la provenienza ed il carattere. Alcuni parlano di Liguri e di Etruschi; certo è che gli abitatori primitivi furono poi sopraffatti da una forte immigrazione dì Celti o Gauli, che invasero e tennero per molti secoli tutta la gran valle del Po.

\footnotetext{
${ }^{2}$ Gnisci (1997, p. 33) discorre sobre a pluralidade que deve se fazer presente em análises inter-culturais.
} 


\section{Capítulo primeiro "QUESTIONE DELLA LINGUA"}

\section{Formação de um italiano regional (séculos XV-XVIII)}

Entre o fim do século XVI e as primeiras décadas do XVII, graças às iniciativas dos cardeais Carlo e Federico Borromeo, surgiram na Suíça italiana escolas, em sua maioria improvisadas nas próprias igrejas e comunidades, que se prestaram à formação básica dos futuros eclesiásticos e quadros da sociedade civil. Nesse momento histórico da ContraReforma era importante, na visão da Igreja Católica, formar uma espécie de escudo, em “defesa da fé”, contra os "hereges reformistas" (BIANCONI, 2005, p. 113).

Embora o cenário político e administrativo local dessas comunidades alpinas fosse mutável e estivesse em evolução, estabilizando-se apenas após o tratado com os franceses, a questão da jurisdição eclesiástica é de extrema importância no processo de manutenção da língua italiana falada no que viria a ser o cantão de Ticino.

Segundo o costume medieval (que persistiu de certa maneira até o início da era moderna com a formação dos Estados nacionais na Alemanha e Itália), as populações católicas estavam sob a jurisdição espiritual, por assim dizer, dos bispos. O que, na prática, significava que a igreja tinha um poder político bem terreno e definido, que atravessava fronteiras, em certas ocasiões.

Ou seja, mesmo com a passagem à esfera helvética, as dioceses de Como e Milão mantiveram-se no âmbito da Igreja Católica, pois era uma prerrogativa do papa enviar quem quisesse ministrar os serviços e cultos em latim ou no idioma que o bispo determinasse. Geográfica e politicamente, a Igreja de Roma tinha interesse em delimitar uma espécie de área tampão dentro dos territórios conquistados, de modo a possivelmente frear o avanço do 
protestantismo, que vinha com os pregadores de fala francesa ou alemã, poucos dos quais falavam fluentemente o italiano.

Diversas ordens religiosas participaram desse empreendimento didático e educacional, mas que também possuía motivações religiosas e políticas. Entre essas ordens, são citadas pelos especialistas: as oblatas do colégio Papio de Ascona e do seminário de Pollegio, os jesuítas e posteriormente os beneditinos do colégio Trefoglio de Bellinzona, os somascos do colégio Santo Antonio de Lugano e do Gallio de Como (BIANCONI, 2005, p. 113).

Isto é, pode-se afirmar que nos territórios da antiga Lombardia setentrional a qualidade do ensino religioso era tão boa e às vezes até superior àquela praticada em Milão, tamanho era o interesse da Igreja em manter sob seu manto espiritual essas populações em uma região (conforme observaremos no próximo capítulo) que era carente em praticamente tudo.

Essas instituições dispunham das mais modernas gramáticas e materiais didáticos para o ensino da língua, conforme aponta o estudioso suíço Bianconi (2005, p. 113):

Sin dall'avvio della loro attività troviamo nelle biblioteche dei collegi i titoli più noti e diffusi delle grammatiche cinquecentesche della lingua italiana: in particolare nella biblioteca del collegio dei Somaschi di Lugano, che avrà un ruolo decisivo nel settore, erano presenti le Prose e Gli Asolani del Bembo, le Grammatices institutiones di Girolamo Cafaro, la Giunta al ragionamento degli articoli di Ludovico Castelvetro, i Fondamenti del parlar toscano di Rinaldo Corso, le Osservationi nella volgar lingua di Ludovico Dolce, le Regole grammaticali della volgar lingua di Gio. Francesco Fortunio, La civil conversatione di Stefano Guazzo, le Institutionum florentinae linguae di Eurosino Lapini, Degli avvertimenti della lingua sopra il Decamerone di Leonardo Salviati, La grammaticheta di Gi. Giorgio Trissino.

Além das gramáticas mais modernas, se comenta que o próprio São Carlos Borromeu, em suas visitas de "inspeção" às escolas do cantão de Ticino, que realizava com afinco, ensinara a arte da redação por meio de leituras e imitações de passagens do Decamerão de Boccaccio. Contudo, por escrúpulo de fé, Borromeu censurava os momentos mais “coloridos" da narrativa (BIANCONI, 2005, p. 114). 
Mesmo com essas exclusões podemos afirmar que, levando-se em consideração a época, os métodos empregados eram realmente de ponta. Esses padres ${ }^{3}$ foram os principais responsáveis por até hoje se falar majoritariamente italiano nas terras do São Gotardo e montes vizinhos.

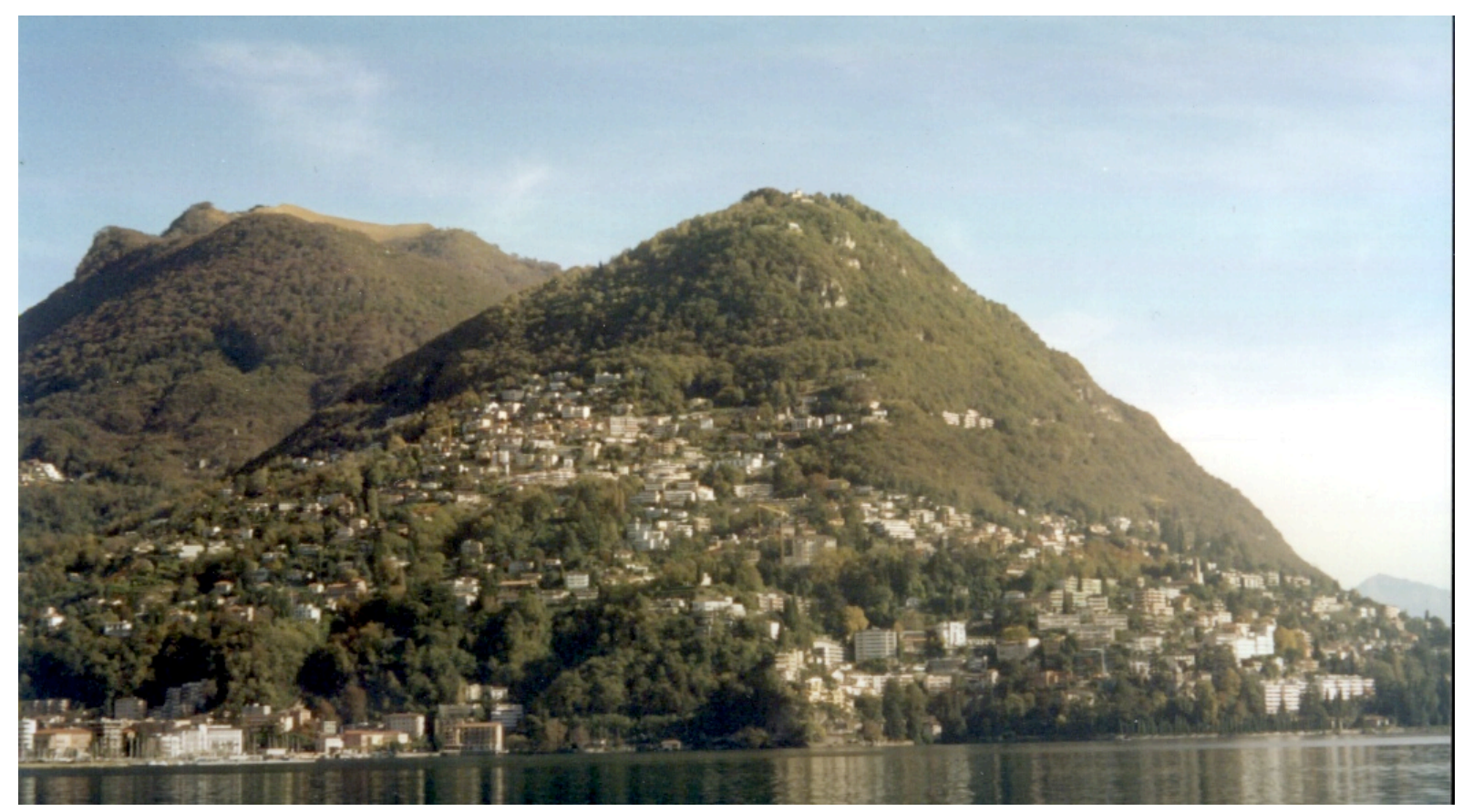

Figura 1 - Vilarejos ‘de cima' e ‘de baixo' da montanha (vista do Lago Ceresio)

Foto: Marcelo E. Redoschi (2001)

Tradicionalmente, os vilarejos 'de cima' eram mais isolados, pois dependiam de transporte e estavam mais sujeitos às intempéries climáticas, sobretudo nas áreas de alta quota. Hoje em dia, estes deslocamentos são realizados em automóvel e também por meio dos 'funiculare' que funcionam como transporte público ${ }^{4}$, tais como nos acessos do Monte Generoso e da própria estação ferroviária de Lugano.

\footnotetext{
${ }^{3}$ Da geração posterior aos irmãos Borromeo é mister citar Francesco Soave (1743-1806), religioso de Lugano. Afirma Bianconi (2005, p. 116). "La figura piú conosciuta e illustre tra i somaschi luganesi è quella certamente del padre Francesco Soave, autore di una serie fortunatissima di manuali scolastici diffusi in patria e in Italia. Insegnò a Parma e Milano nel collegio di Brera e divenne direttore generale delle scuole elementari di Lombardia. Trasferitosi a Lugano dopo l'arrivo dei francesi ebbe allievo il Manzoni nel collegio S. Antonio. Tornò in Italia e tenne la cattedra di Analisi delle idee a Pavia dove mori’"
}

${ }^{4}$ Observação in-situ do autor. 


\section{$1.2 O$ italiano oitocentesco}

O filólogo e dialetólogo Lurati comenta que conservadorismo e aulicismo predominam na organização do linguajar administrativo no Oitocentos ticinense, de forma paralela à tradição da língua de chancelaria presente no antigo Ducado de Milão. Contudo, com o novo século (em 1882, a abertura da Galeria do São Gotardo e o correspondente aumento dos contatos com outras zonas suíças) trazem o influxo de outras tradições lingüísticas, ou seja, do francês e alemão (LURATI, 1976, p. 169).

Se esses aportes lexicais foram tênues no século XIX (cf., por exemplo, os termos: dipartimento, comune, cantone, municipio e também bosco sacro, dicastero, insinuare, lodevole), posteriormente este fenômeno se amplia (LURATI, 1976, p. 169).

Embora uma análise pormenorizada dos dialetos da região esteja além do escopo deste trabalho, são necessárias, contudo, certas contextualizações de base.

Notamos na apresentação (p. 16) que na época de Chiesa já se dava como certo que a região pré-alpina onde se encontram os atuais cantões de Ticino e dos Grigioni Italiani fôra inicialmente colonizada pelos celtas. Com o posterior advento dos romanos, foi trazida a cultura latina, cujos reflexos persistem até hoje, assim como em outras partes da Confederação Helvética (ex.: "Suisse Romande", que significa "Suíça de expressão francesa").

Com efeito, Lurati afirma que o dito processo de latinização é o fato maior da história dessas populações de montanha. Determinou, portanto, segundo o estudioso, durante o passado e persistirá em séculos vindouros sua maneira de ser e de interpretar o mundo (LURATI, 1976, p. 50).

No período medieval e pré-industrial havia o predomínio da agricultura e das profissões ligadas ao artesanato nessa região. Os dialetos locais sofreram influência sobretudo 
do italiano, em um sentido amplo, cultural. Ou seja, mais que fornecer as estruturas sintáticas ou denominadores lingüísticos, o italiano (referimo-nos aqui estritamente à língua oral e do convívio familiar, uma vez que a escrita denominada culta era aquela oficial, ensinada pelos padres, no modelo florentino) exportaria, por assim dizer, seus termos culturais e abstratos, enriquecendo o dialeto, cujo léxico estava ligado à vida prática (LURATI, 1976, p. 85).

Lurati comenta que existem três tipos de registro lingüístico nessas populações, conforme a localização física, geográfica do locutor. Ou seja, até o Oitocentos (e em certa medida o início do Novecentos) era comum um agricultor ou artesão se comunicar em dialeto local em seu vilarejo e arredores, no dialeto regional $1^{5}$ quando fosse comprar mantimentos ou vender seu gado no centro regional mais próximo (ex.: Locarno, Lugano, etc.). Além desses dois falares, que procuramos ilustrar, o habitante dos Grigioni ou de Ticino também dominava o italiano padrão, das interações formais e dos grandes centros históricos da Lombardia (i.e., sedes episcopais), Como e Milão.

Em termos sintéticos, como resultado de nossas leituras da questão da língua, podemos afirmar que o italiano falado na Suíça é fruto de contribuições (assim como de diluições e depurações), que, tal como águas minerais alpinas, brotam nas fontes dialetais locais, que desembocam nas maiores, regionais, aos pés dos Alpes, e que por sua vez escorrem até ultrapassar a fronteira e atingir os centros da planície setentrional italiana.

Com o passar do tempo, as formas dialetais mais distantes do italiano, inclusive na maneira física de construção do som e posicionamento (ex.: uso de explosivas médio-palatais) foram progressivamente sendo substituídas por expressões "simplificadas" em italiano. (LURATI, 1976, p. 50).

\footnotetext{
${ }^{5}$ Há uma multiplicidade de dialetos na Suíça italiana, de acordo com Lurati (p. 45).

"Il processo è: dialetto locale $>$ dialetto regionale $>$ italiano regionale $>$ lingua standard" (p. 111).
} 


\subsection{Início do Novecentos}

Acerca da importância do estudo do italiano regional falado na Suíça dentro dos estudos de lingüística e cultura italiana, afirma Ottavio Lurati (1976, p. 117):

Significato e interesse del tema sono chiari. La perifericità, l'essere agli estremi confini dell'italianità, il quotidiano contatto con modelli culturali e linguistici francesi e tedeschi rendono tutta particolare la condizione linguistica della Svizzera Italiana e assegnano all'italiano regionale ticinese un interesse non solo locale ma più ampio nel quadro della linguistica italiana. Oltre all'opportunità di studiare in concreto la problematica di lingue in contatto, si ha qui l'esempio del destino di una piccola comunità in uno stato con pluralità etnica, linguistica e culturale. L'interesse è di esaminare come una forza regionale, protetta da una legislazione adeguata, riesca a mantenersi da un lato, a caratterizzarsi linguisticamente dall'altro.

Aqui estão colocadas as questões centrais referentes à língua no século XX, em que eclodiram duas guerras mundiais e inúmeros conflitos. A histórica proximidade com outras culturas, que oferece importantes e enriquecedoras perspectivas culturais, também pode ser foco de tensão entre essas fronteiras lingüísticas.

Em certos casos, a convivência se dá de forma harmônica, no exemplo das comunidades bilíngües, onde a poucos minutos de distância de automóvel, ou até mesmo ao atravessar-se uma rua ou ponte, notam-se as diferenças. De especial preocupação aos estudiosos dessa questão sociolingüística são os enclaves, independentemente do idioma em particular.

Conforme observado anteriormente, por exemplo, desde 2000 a comunidade alpina de Bosco Gurin, de secular colonização “alemã”, passou a fazer parte da Suíça de língua italiana, com possíveis conseqüências para o importante legado cultural da região. Ou seja, a questão da língua por vezes se intersecta com o conceito de identidade individual e coletiva. Quer dizer, é correto afirmarmos que uma região, ao tomarmos o caso brasileiro, faz parte de uma determinada cultura se tomarmos como barômetro somente a língua? 
Por exemplo, são Blumenau ou Pomerode verdadeiramente "alemãs" quando a maior parte de sua população emprega o português em vez da língua de Goethe e Schiller? É necessário que se recorra ao idioma da "pátria cultural" de modo a se sentir alemão, brasileiro, ou italiano?

Pelo próprio fato de termos na Suíça uma situação distinta da do Brasil, principalmente em relação à pluralidade de idiomas e diferença de extensão territorial, onde tanto o alemão quanto o italiano, duas línguas nacionais helvetas, coexistem em uma espécie de colcha de retalhos bem organizada, verdadeiro "patchwork" alpino.

Em linhas gerais, existe um consenso cultural na Suíça, imbuído no tecido nacional, de que as especificidades e diferenças regionais das comunidades francesa, italiana, romanche (e até mesmo suíço-alemã onde coexistam falares minoritários) têm, de certa maneira, de ser levadas em conta, pois fazem parte do próprio conceito de país multiétnico.

Seja como for, essa questão da possível italianização de um enclave germanófono, que vem desde a época da Lombardia medieval, com prejuízos a uma história cultural de Ticino e da Suíça, provavelmente será verificada outra vez no próximo censo lingüístico. É bem possível que isso gere futuras discussões no país.

Empregamos, pois, o exemplo a cima de modo a ilustrar que "polêmica lingüística" é algo antigo na Suíça em geral e em Ticino em particular. Em meados do século XX, há cerca de sessenta anos, Francesco Chiesa, que também exercia atividades de jornalista, ao colaborar com revistas literárias e de política, estava no campo daqueles intelectuais que veementemente defendiam a preservação da italianidade de sua região dentro do contexto cultural plural helvético.

Uma das preocupações de Francesco Chiesa, que passaram à literatura e encontram-se refletidas em suas obras, em escritos como Tempo di marzo, é justamente essa questão 
identitária, por meio da preservação da língua e da memória de uma identidade regional, conforme iremos observar mais adiante, no próximo capítulo.

Em outras palavras, Chiesa (e certos extratos da intelectualidade local) tinha o receio de que sua região progressivamente se tornasse um enclave onde, a partir da germanização das cidades maiores, vilarejos rurais inteiros viessem a ser aculturados e eventualmente toda essa herança cultural dos dialetos e do italiano regional desaparecesse.

Vale lembrar que esse era um temor extremo que se revelou desproporcional, mas parte disso já ocorrera em áreas remotas da Suíça italiana, no cantão dos Grisões e sobretudo na dita Suíça romanche, onde um a um esses municípios vêm sendo progressivamente germanizados.

Por isso, a questão identitária era amplamente justificada (em teoria, pois na realidade as línguas são entidades vivas que recebem aportes de outros idiomas, quer seja o alemão, o francês ou o inglês, como podemos observar pelo crescente influxo de anglicismos na mídia italiana, que rotineiramente emprega neologismos como "postation", sem mencionar o já consagrado "privacy").

De natureza pessoal reservada e até tímida, afirmam os registros que Chiesa se tornava um gigante quando entravam em jogo essas questões da língua. Seu empenho, juntamente com o de alguns intelectuais e personalidades ticinenses que entendiam que a preservação do idioma de Dante caminhava pari passu com uma definição de identidade regional, foi contundente.

Conforme já discorrido e como bem nos lembra Lurati, esses aspectos econômicos e sociais também afetavam o delicado equilíbrio lingüístico suíço em geral e em particular da Suíça italiana. Seria concebível supor, por exemplo, que "imigrantes" suíço-alemães vindos de Zurique ou Lucerna (a meros de 100 quilômetros de distância, mas separados pelas alturas 
dos Alpes e por histórias milenares, distintas) quisessem que seus filhos continuassem a freqüentar estabelecimentos de ensino em língua alemã. Contudo, aqui vale lembrar a já explicada especificidade helvética, onde, diferentemente dos estados brasileiros, os cantões tem grande autonomia. Na prática, funcionam como uma espécie de mini-países, guardadas as devidas proporções, bem ilustradas pelo próprio nome do nosso objeto de atenção: "Repubblica e Cantone Ticino".

\subsection{0 "florentinismo" de Chiesa em defesa da língua}

A respeito do estilo e reconhecimento de sua obra na Itália, comentou da seguinte forma Raffaele Russo, na época diretor de uma revista literária romana entitulada "L'eloquenza" (AGLIATI, p. 169. v. 2).

Francesco Chiesa non ha bisogno di presentazione per i nostri lettori. Poeta ed anche prosatore fra i più robusti, egli ha rivelato il suo cuore e il suo ingegno nobilissimo in numerose opere che incontrarono il consenso della critica più autorevole e del nostro pubblico, che lo predilige. Giustamente lo predilige, perché Francesco Chiesa ha cuore e spirito italiani. Non solo perché egli in Italia compì i suoi studi; non solo perché egli per molti anni insegnò lettere italiane e la storia dell'arte nel liceo di Lugano del quale oggi egli è Preside, ma perché, cogli scritti e con la parola, fu uno dei più appassionati divulgatori ed insieme uno strenuo difensore della nostra lingua, delle nostre tradizioni, della nostra storia fra i conterranei del suo Ticino : per quest'opera tenace, illuminata, amorosa da lui compiuta merita la riconoscenza ed insieme l'affetto di tutti noi

O depoimento acima corrobora alguns fatores. Primeiro, Chiesa era conhecido e apreciado pela crítica e público italianos, bem além das fronteiras com a Lombardia. Segundo, exercia atividades múltiplas, em sua maioria voltadas ao universo da cultura italiana. Por décadas lecionou língua, literatura e história da arte em Lugano, onde posteriormente foi diretor do colégio. Advogado de formação e de família de pintores e artesãos, dedicou-se com afinco ao magistério e a transmissão da cultura de origem italiana às novas gerações. 
Sobre os edifícios, escultoras e pinturas do renascimento, escreveu Chiesa (1928, p.

20)

Durante il secolo XV, nel nostro paese si continuò (salvo casi eccezionali) a costruire, a dipingere, a lavorare la pietra conformemente alle usanze ad allo stile del Medio Evo. Ma fin dal principio di quel secolo, in Firenze aveva incominciato a farsi strada una nuova forma d'arte, che man mano si estese di centro in centro, di regione in regione; ed al principio del sec. XVI ottenne una decisa vittoria anche in Lombardia. A tale vittoria contribuirono potentemente, con l'esempio delle loro grandi opere, due sommi artisti, Leonardo da Vinci toscano, e Donato Bramante marchigiano, chiamati a Milano da Lodovico il Moro, signore di quella città e rimastivi per una lunga serie di anni. Da Milano, da Como, dagli altri principali centri lombardi (sempre attentivamente frequentati dagli artigiani e dagli artisti del lago di Lugano) il nuovo stile si diffuse poco a poco in tutto il nostro paese.

Florença foi portanto, no campo da arte, nas palavras do próprio Chiesa uma espécie

de "centro de centros", de onde se irradiou um saber e fazer artístico que ganhou a Europa.

Por conseguinte, quando recebeu o convite para discursar na renomada sociedade

Dante Alighieri de Roma, sentiu-se grato em representar seu Cantão em um evento cultural na península ${ }^{6}$. Realizou um discurso onde citou a italianiedade do Ticino. Importante ressaltarmos aqui sua menção ao "gênio da estirpe italiana" que atravessa os séculos, uma clara referência à sobrevivência do italiano em seu país, onde as línguas e culturas de origem latina, embora oficiais, sempre foram historicamente minoritárias.

Neste registro temos a oportunidade de observar a oratória de Chiesa, sua eloqüência é digna do nome da revista que lhe convidara a realizar o discurso. Se considera altamente honrado pela recepção. Em sua fala faz referência às contribuições de seu povo à obra do sumo poeta florentino cuja qual vê quase como sagrada, solene.

\footnotetext{
${ }^{6}$ Agliati (p. 169) indica que a conferência ocorreu em 29 de Março de 1935. O poeta, como certa parte da intelectualidade de Lugano, mantinha uma grande admiração cultural pela Itália. Contudo, isto nunca se traduziu em uma adesão formal ou informal que fosse ao movimento fascista, haja visto o princípio fundamental da neutralidade helvética (cfr. Mangan p. 34-35).
} 
Signore e Signori! Parlare a Roma, per invito della Dante Alighieri, è onore altissimo e, per me, impegno grave. Ho tuttavia accettato e con profonda riconoscenza, pensando che avrei potuto recarvi altro e più che la mia voce personale. Io sono un uomo della Svizzera italiana; uomo d'un paese che è sempre stato e deve rimanere italiano di lingua e di spiriti. D'un paese che, alla solenne opera in cui s'afferma attraverso i secoli il genio della stirpe italiana, ha dato un contributo importante, costante, d'insigni valori individuali e d'attività collettiva. Questa secolare cooperazione del mio paese alla grande opera comune, ho pensato che possa essere l'argomento del mio breve discorso (AGLIATI, p. 170, vol 2).

Conforme observamos acima, essa questão da defesa do emprego do italiano, língua minoritária do país, mesmo tentando se ater a discussões eminentemente técnicas, rapidamente pode atingir conotações políticas, no contexto multi-cultural suíço.

Comenta Lurati: “Ma a noi il problema preme soprattutto per le sue implicazioni politiche e culturali: la cultura e la lingua italiana rappresentando una delle componenti essenziali della facies culturale e umana della comunità svizzera".

Francesco Chiesa, além de poeta, escritor e identificado com o grupo dos "italianistas" ticinenses, era advogado de formação, graduado na Universidade de Pavia (1891). Com essa educação formal no campo das leis, e por acreditar que a presença (que a nossos olhos, cem anos mais tarde, aparentemente seria "inocente" e bem-vinda) de uma escola bilíngüe ou monolíngüe afetaria o equilíbrio lingüístico e a própria "sobrevivência cultural” de sua região, fez campanha e finalmente conseguiu que leis cantonais na área da educação "protegessem" o italiano, dando-lhe lugar 'reservado' nos liceus.

Essa componente biográfica de Chiesa é importante, pois seu "movimento político" por assim dizer, em defesa da língua, cultura e patrimônio histórico foi traduzido em mais do que legislação, é presente em sua escrita, foi incorporado, por assim dizer, à sua própria maneira de pensar-se como escritor. 
Em defesa de Chiesa, devemos ressaltar que naquela época realmente havia um temor racional e fundado em relação ao italiano, de que, se ocorressem migrações em massa (observamos que a abertura da ligação ferroviária do São Gotardo foi feita em 1880) de aposentados vindos do norte em busca de seu cantinho de sol, finalmente as lojas e o comércio do cantão trocariam todos os seus sinais de 'alimentari' para 'Essen', de 'strada' para 'Strasse', de 'libreria' para 'Buchhandlung'.

Havia portanto o risco real de que essas estruturas se enfraquecessem a ponto de a própria língua, a própria identidade local desaparecer. Falando em um contexto mais atual e geral, o que demonstra a permanência, de certa forma, desse 'perigo latente' de absorção de comunidades inteiras italófonas pela cultura economicamente mais forte, afirma Lurati: “ $L a$ sua scomparsa o il suo indebolimento costituirebbe il fallimento dell'intero assetto federativo. Il mantenersi, anzi la vitalità della cultura e della lingua italiana nel Ticino e nelle Valli grigioni-italiane è essenziale alla struttura federativa della Svizzera”. (LURATI, 1976, p.

Essa previsão do estudioso suíço três décadas atrás (ecoando, por assim dizer, um temor do próprio Chiesa e de italianistas como ele no início do XX) se concretizou de certa forma nos Grigioni, onde os dados recentes (censo) mostram que o italiano tende a desaparecer em certos vales alpinos, devido ao isolamento geográfico (que será comentado no contexto da obra Tempo di marzo, em caráter ilustrativo no próximo capítulo) e à presença de escolas com ensino praticamente apenas em alemão (em detrimento do romanche nativo e do próprio italiano).

É mister notar que atualmente se fazem esforços para incentivar essas populações a falarem italiano (sobretudo os jovens) em casa com os pais. O empenho da fundação Pro Grigioni Italiano fez com que algumas escolas de ensino fundamental desse cantão 
(Graubünden) incluíssem o idioma de Dante em sua grade curricular, em uma tentativa de manter viva a língua nesses vilarejos de indescritível beleza natural, mas de certa forma ainda isolados no tempo e no espaço. Longos deslocamentos têm de ser feitos, por aqueles que desejam continuar os estudos, até Curia, capital administrativa e sede histórica (i.e., do bispado) da região.

A questão das escolas é mencionada neste trabalho por abranger um importante aspecto biográfico de Francesco Chiesa. O poeta ticinesense foi durante trinta anos professor de língua italiana e posteriormente história da arte (cujo movimento renascentista italiano, ou mais especificamente florentino, consiste em um alicerce da cultura ocidental).

Originário da classe média, Chiesa, como tantos outros ticinenses em sua época, seguiu o oficio da família e o percurso de seus conterrâneos (devido à então ausência de uma universidade de língua italiana em seu cantão), e optou pelos estudos na Itália, por sua proximidade cultural, em vez de Zurique, Friburgo ou Genebra, reconhecidos centros universitários, mas com currículos em outros idiomas.

Chiesa, já nos tempos de Pavia, despontava com grande vocação poética. A advocacia, iria exercê-la, após seu retorno a Lugano, durante cerca de um ano e meio, quando vencera um concurso de poesia, organizado pelo cantão. Coberto de honras, em uma tenra idade, foi-lhe oferecida uma possibilidade que também vinha carregada de uma grande carga de responsabilidade: ser professor de língua italiana por tempo integral no liceu cantonal, empenho esse que ele aceitou e no qual mergulhou com afinco e dedicação.

É sabido e reconhecido que escritores influenciam escritores. Contudo, como não havia, segundo os estudiosos da época, uma produção literária stricto sensu, entendida aqui como o fazer de belles lettres, aquele ato do pincelar artístico das palavras, Chiesa buscou então sua inspiração, seu material básico de construção, seus tijolos, se podemos nos permitir 
o emprego de tal analogia, no mais puro mármore florentino que foi Dante. Grande estudioso da obra de Dante, o ticinense Chiesa tem Alessandro Manzoni como sua outra grande fonte de inspiração literária e admiração pessoal, conforme veremos a seguir.

Em comemoração do nonagésimo aniversário de Francesco Chiesa, foi realizada uma série de programas na radio suíça em comemoração da data. O som de algumas dessas antigas transmissões educativas da RTSI foi preservado em formato digital e disponibilizado na rede mundial de computadores.

A terceira dessa série de cinco programas abordara a narrativa de Chiesa, com leituras de textos de seus romances e comentários de críticos a respeito de Santa Amarillide (seu terceiro romance), Villadorna (obra de 1928 e vencedora do prestigiado prêmio da Academia Mondadori) e Tempo di marzo (de 1925, objeto deste capítulo do trabalho e obra mais conhecida de Chiesa no exterior).

Sua longevidade e vigor literário, Chiesa ficou conhecido como $<<$ l'artefice malcontento $>>$ por sua verdadeira obstinação em aperfeiçoar seus escritos, sobretudo a obra poética. $\mathrm{Na}$ tabela seguinte, apresentamos um quadro sintético de sua extensa produção (inspirado em CALGARI 1968, p. 318 e 319). 


\section{Tabela 1 - Quadro sintético da produção Chiesiana}

\begin{tabular}{|c|c|}
\hline Preludio & Poesia - 1897 \\
\hline La Cattedrale & Poesia - 1903 \\
\hline La Reggia & Poesia -1904 \\
\hline Calliope & Poesia $\sim 1907$ - 2- ed. 1921 \\
\hline I viali d'oro & Poesia - 1911 - 2- ed. -1921 \\
\hline Istorie e favole & $\begin{array}{l}\text { Conto - } 1913 \text { - reeditado parcialmente em Voci nella } \\
\text { notte - } 1935\end{array}$ \\
\hline Fuochi di primavera & Poesia -1919 \\
\hline Racconti puerili & Conto -1920 - 2- ed. 1935 \\
\hline Consolazioni & Poesia - 1921 \\
\hline Vita e miracoli di santi e di profani & $\begin{array}{l}\text { Conto - } 1922 \text { - reeditado parcialmente em Voci nella } \\
\text { notte - } 1935\end{array}$ \\
\hline Tempo di marzo & $\begin{array}{l}\text { Romance - } 1925 \text { - Treves, depois } 1938 \text { Mondadori e } \\
1956 \text { SEI }\end{array}$ \\
\hline Villadorna & Romance - 1928 \\
\hline Racconti del mio orto & Conto -1929 \\
\hline Compagni di viaggio & Conto - 1931 \\
\hline Svizzera italiana & Prosa -1931 \\
\hline La stellata sera & Poesia. 1933 \\
\hline Scoperte nel mio mondo & Conto -1934 \\
\hline Voci nella notte & $\begin{array}{l}\text { Reedição parcial de Vita e miracoli e de Istorie e favole } \\
-1935\end{array}$ \\
\hline Scritti vari, editi e inediti & 1935 \\
\hline Sant'Amarillide & Romance - 1938 e 1967 \\
\hline Passeggiate & Conto - 1939 \\
\hline Racconti del passato prossimo & Conto - 1941 \\
\hline Io e i miei & Romance - 1944 \\
\hline Ricordi dell'età minore & 1948 \\
\hline La scatola di pergamena & Prosa - 1960 \\
\hline Altri racconti & Conto - 1964 \\
\hline Sonetti di San Silvestro & Poesia - 1971 All'insegna del pesce d'oro \\
\hline
\end{tabular}


Francesco Chiesa, em entrevista à radio suíça de língua italiana (RADIOTELEVISIONE SVIZZERA DI LINGUA ITALIANA), afirmou:

Manzoni è quello cui si torna e si ritorna... e non so dirlo... come lettura letteraria se posso dire ma anche come consolatore. A me è capitato qualche volta, non so, in certi risvegli della notte, certi risvegli determinati forze o prolungati da pensieri importuni. Discendere dal letto, di andare una certa scansia, di cercare il mio Manzoni. Di rileggere qualche pagina, così, semplicemente per trovarmi al contato col mondo il quale parlando di cose che poi non avevano niente che fare col mio stato d'animo, me distendessero.

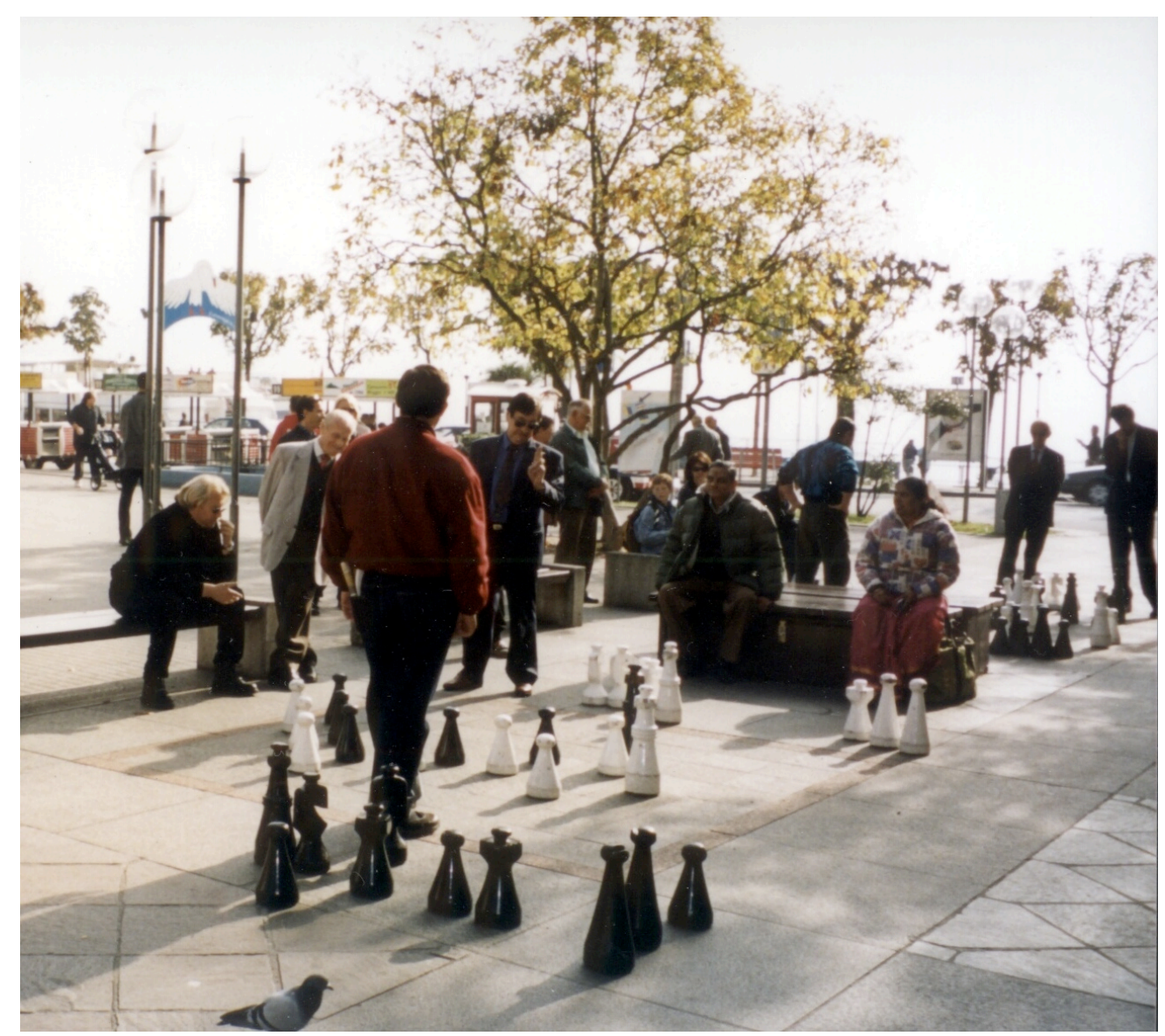

Figura 2 - Xadrez gigante de rua em Lugano (próximo ao cais)

Foto: Marcelo E. Redoschi (2001) 


\section{Capítulo segundo}

\section{MEMÓRIA CULTURAL EM TEMPO DI MARZO}

\subsection{Referências à agricultura lombarda medieval}

O romance em si inicia-se com a imagem do bicho-da-seda, que, se o interpretarmos em um conceito universal, nos remete à confecção artesanal das próprias roupas. Essa é portanto, uma gente que trabalha a terra, com poucos recursos, e que extrai da natureza seu sustento. Além disso, talvez exista um outro significado, complementar, mais ligado às tradições da região. Na vizinha Lombardia, até hoje nas comune rurais da planície lombarda celebra-se a lenda do Beato Giobbe, que trazia prosperidade e cujo símbolo era o bicho-daseda.

L'anno delle disgrazie (tristemente famoso nelle cronache della mia famiglia) cominciò così. Una mattina in sul principio di maggio, stavamo seduti, il babbo, la mamma ed io, sotto il portico di casa; i piccini giocavano tranquillamente nel cortile. La mamma sceglieva e componeva in forma di mazzo le foglie di gelso da tritare per i bachi da seta, che cominciavano a nascere. (CHIESA, 1984, p. 1)

O período de maturação do Ticino moderno foi longo. De 1516 - quando as últimas tropas milanesas foram derrotadas na região de Locarno e Lugano, cujo domínio passou, com a dita "Paz de Friburgo", de Francisco I da França aos suíços - até 1798, passaram-se quase três séculos. Nesse período estas populações foram súditas dos diversos governadores (conhecidos como "Landfogti") mandados alternadamente pelos cantões do norte administrar a espécie de "protetorado" que tinha se tornado a região geográfica do Vale do São Gotardo (Calgari, 1968, p. 278). 
A terra natal do poeta foi assolada por inúmeras carestias durante esse período. O povo era em sua maioria camponês, paupérrimo. Por vezes nem o senhor feudal enviado pelos cantões centrais escapava dos efeitos dessa crônica penúria.

Comenta o sítio oficial da prefeitura de Mendrisio: (STORIA DI MENDRISIO)

La povera gente, cioè quasi tutta la popolazione, ricavava lo scarso pane dalla terra, penalizzata spesso dalle carestie: almeno due flagellarono il Borgo nel XVI secolo, una terza di sicuro imperversò attorno al 1623 e colpì anche in alto, tanto che neppure il Landfogto aveva da mangiare.

Dentro desse quadro de miséria estarrecedora, restava ao povo se arranjar como pudesse. Existem casos documentados desses expedientes, onde, por motivo de penúria, se burlava a lei. Um, de 1573, informa-nos que era difundida a prática de deixar "sem querer" os animais ruminarem na propriedade alheia para se economizar capim, tamanha era a carestia. Por um registro de 1591, sabemos que se pescava clandestinamente. Havia também aqueles que faziam misturas e adulterações alimentares para vendê-las, em momentos de desespero, a preços muito superiores a aqueles permitidos por lei.

Continua a prefeitura, que ela própria agora faz um pouco de transposição literária: "Naturalmente também se roubava (ou, melhor dizendo, 'surrupiava') bastante, mais por necessidade do que por maldade: um pouco de lenha dos bosques e alguns frutos de jardim (STORIA DI MENDRISIO).

In tanta miseria molti si arrangiavano come potevano, e le gride in proposito sono parlanti. Una, datata 1573, informa che era diffuso il malvezzo di lasciar pascolare il proprio bestiame nei campi altrui per risparmiare foraggio; da un documento del 1591 sappiamo che si pescava di frodo; e poi c'era chi faceva incetta di grano e di altre derrate alimentari per venderli, in momenti di penuria, a prezzi più alti di quelli stabiliti per legge. E naturalmente si rubava (o meglio: rubacchiava) molto, per necessità, non certo per cattiveria: un po' di legna da miseri boschi e qualche frutto da poveri giardini erano il magro bottino. 
Quando a irmãzinha de Nino, Pia, é acometida de uma forte tosse, a Senhora Lucia, que excepcionalmente cuidava dos meninos enquanto a mãe estava fora, diz ao garoto que busque camomilas frescas em seu jardim (CHIESA, 1984, p. 133). O Menino, que vê tudo como aventura, prontamente vai.

Ad un tratto, m'arrestai, coi capelli dritti, con il cuore che mi si spezzava, con i ginocchi che mi si sfacevano... C'era qualcuno, nell'orto ... Non era già l'aria tra le fronde, oh no... Rimasi li inchiodato, due minuti forse; un'eternità. Non si udiva più nulla di particolare. Mi venne in mente una cosa: che forse quel tonfo (un tonfo avevo udito, ed insieme uno sfusciare, come se qualcuno fosse saltato giù dal muro), dunque che forse quel tonfo era stato un pomo... Un pomo che si stacca dal suo ramo e cade fra le foglie e batte sul terreno, fa ben così... No?

Contudo a chegar lá, sente medo pois escuta um misterioso barulho (CHIESA, 1984,

p. 133).

La disperazione può essere una cosa provvida. Tant'e vero che questo poverello di ragazzo si lanciò alla volta del cespuglio gridando con la sua voce più terribile:

Chi è là? - E aggiunse una serie di urli feroci, ch' erano la voce della sua paura adoperata per far paura. Un'altra voce, dello stesso genere, rispose dal cespuglio. Poi le due voci si riconobbero e, da una parte e dall'altra, la paura svanì.

- Sei tu, Beniamino?

- Sei tu, Nino?

Ma si! Era il mio amico Beniamino, in carne ed ossa, entrato dalla parte del muro per fare una visita alle pere della signora Lucia.

Era seu amigo Beniamino que viera buscar, como de costume dos meninos "levados"

da região, a sobremesa no orto dos outros. Isto era feito por um misto de estripulia e necessidade, pois eram pobres. De modo a explicar o ocorrido à Sra. Lucia, Nino inventa uma história heróica e rocambolesca, em seu melhor estilo infantil (CHIESA, 1984, p. 133).

- Sei un bel ladro, sai? - gli dissi bonariamente. Nello stesso tempo, io aiutai a riempirsi le tasche, lo dissuasi dall'inutile fatica di scavalcare un'altra volta il muro e tutt'e due uscimmo tranquillamente per la porta, adoprando la bella chiave della signora Lucia, Alla quale, appena tornato a casa, raccontai, con molti particolari, del ladro che avevo sorpreso nel suo orto: un ladro che non avevo potuto riconoscere, tanto presto era fuggito, tanta paura gli avevo fatta! 
Em 1803, graças à intervenção de Napoleão Bonaparte, que por razões militares e estratégicas queria manter intacta a confederação, Ticino torna-se "República autônoma e cantão".

Alguns anos antes, a formação de uma República Cisalpina livre do domínio estrangeiro, nos confins do Ticino, fez com que a população se rebelasse e proclamasse sua decisão de viver "livre e suíça". No entanto, essa memória dos tempos de carestia persistiria até a primeira metade do $\mathrm{XX}$, quando a região começou a ficar próspera, com a indústria do turismo.

\subsection{Terra de camponeses rústicos}

Mesmo com a independência regional, arduamente obtida, a região continuava isolada. Território verdadeiramente ensanduichado entre os domínios dos maiores impérios europeus de sua época, o cantão recém-independente via-se diante da hercúlea tarefa de construção de uma infra-estrutura física.

Comenta Guido Calgari (1968, p. 279):

Da quella data comincia uno sforzo esemplare per costruire - dal nulla di tre secoli di soggezione - il proprio edificio statale moderno: strade e ponti, agricoltura e commercio, finanze e istruzione pubblica, legislazione, igiene, milizia... Sforzo tanto piú notevole, in quanto contrastato dall'inimicizia di grandi potenze: il Regno Italico prima, l'Impero Austro-Ungarico poi, dalle lotte feroci tra i partiti politici locali, dall'isolamento economico che fu la cruda conseguenza della nuova Costituzione svizzera del 1848 (avocante al governo centrale la direzione della politica e della politica doganale di tutta la Svizzera), e della formazione del Regno d'Italia - 1861 - che si circondò anch'esso di dogane e considerò il Tícino quale paese straniero.

Em Tempo di marzo, o pai do garoto, ávido por novidades, vasculha no jornal velho tal como um pão vencido mas que ao mesmo tempo é saboroso, pois o único de que dispõe, devido à miséria do isolamento e à falta de oportunidades - por alguma coisa interessante que 
possa ter passado desapercebida: "Il babbo, nell'attesa della posta che gli portasse il giornale nuovo, cercava nel giornale del giorno prima qualche cosa che avesse ancora un sapore." (CHIESA, 1984, p. 1).

Observa Calgari (1968, p. 279) quanto à situação da época:

Furono anni d'immensa miseria e di rovinosa emigrazione. Con l'apertura della linea ferroviaria del San Gottardo (1882) si stabilì finalmente una comunicazione ininterrotta tra il Cantone meridionale e la patria svizzera, rovesciando però l'economia ticinese verso l'innaturale mercati del nord; la questione comunque potrebbe essere indifferente se le tariffe del viaggio fossero state sopportabili e se l'economia del Ticino si fosse sentita preparata come quelle d'oltralpe; le tariffe dei trasporti furono invece per lungo tempo rovinose (ancor oggi il Ticino vorrebbe condizioni migliori per superare il... deserto montagnoso che lo separa da Zurigo, Basilea, Lucerna...) e l'economia del paese era impreparata per mancanza di capitali, di tecnici, di inscrizione professionale.

No romance de Chiesa, a família do protagonista era humilde, mas como o pai tinha instrução, era considerada de maior nível social que as dos lavradores e camponeses: "Già, il babbo era geometra. Ed era strano che io mi sia fin ora dimenticato di dirlo, non essendo pochi $i$ vantaggi che venivano a me da quell'esser figlio di geometra" (CHIESA, 1984, p. 92).

Segue-se a descrição maravilhada (ex.: sabor bom que lembra aquele - das balinhas de - anis) e superlativa (quarto enorme, mesa grande do tamanho de uma praça, etc.) do menino, com os aumentativos característicos do falar infantil (CHIESA, 1984, p. 92).

Onore a parte, quello stanzone al secondo piano ch'era lo studio del babbo, non l'avrei barattato con una reggia: quello stanzone con in mezzo una tavola grande come una piazza; e sulla tavola una tavola grande come una piazza; e sulla tavola ogni bene di Dio: compassi, squadre, tiralinee, puntine, gomme, penne di tutte le qualità, in tanta abbondanza che, a portarne via due o tre nessuno se ne accorgeva... E scatole di colori e bastoncini d'inchiostro di China, di quel fino, che ha un odore e perfino un gusto buono, in sul fare della liquirizia, non quel saporaccio infame dell'inchiostro ordinario... Quei livelli ad acqua, quei traguardi, tutta quella bella carta da disegno...

Embora o senhor Andrea fosse um competente agrimensor, tanto na ficção do livro quanto na realidade o Ticino da virada do século XX era uma área pobre e isolada. $\mathrm{O}$ falar de 
Nino é autêntico, aquele de um menino do início do XX, cuja língua materna é indubitavelmente o italiano. Agora, localizar exatamente a cultura, por meio do registro lingüístico somente, já é uma tarefa mais complicada.

Esse conhecimento da região, por assim dizer, chega a nós gradual e progressivamente, por meio daquelas informações contextuais, "não lingüísticas", estritamente falando. Quer dizer, à medida que o menino transcorre o final de sua infância, relatada nos capítulos de Tempo di marzo, é que passamos a conhecer melhor a geografia, usos e costumes de sua região. Os percursos de Nino servem para nos mostrar e fazer-nos conhecer um pouco das sutis diferenças da Vico "de cima" e da Vico de baixo, certamente um relato ficcionalizado, mas baseado em grande parte na própria infância e experiência de vida do autor (conforme ele mesmo afirma em entrevista à Radio e Televisão Suíça, em italiano, à época de seus 90 anos, em 1961).

Tal como nesta peregrinação da família, na festa da Madonna (CHIESA, 1984, p. 242):

- Il bicchiere, lo beva lei, signor Andrea. A me basta il vino che c'è dentro.

- D'accordo. E quante grazie avete portate via alla Madonna?

- Ma?... Qualche cosa ci ho ben qui...

(E faceva l'atto di palparsi sulla giacca il gonfio della tasca)...

- E chi avete trovato lassù a Montetoro?

-Un fulmine di gente. Ne son venuti fin dalla Bassa: due giornate di viaggio. E poi da tutta la valle di San Primo, da Albanella, da Ravignano, da Castelletto.

As descrições geográficas dos tempos e distâncias, medidos em dias, entre os vilarejos distantes são bastante indicativas. Na época eram calamitosas as estradas do cantão de Ticino, isto é, quando existiam esses caminhos, e o terreno íngreme.

Comenta um artigo técnico de geografia, acerca da situação, que o cantão era montanhoso, pobre e isolado, e com escassez de recursos. Mal havia comunicação com o restante do mundo ou alguma espécie de mercado (interno) para produtos industrializados. Mesmo assim, comenta o especialista, os ticinenses encontraram um meio de melhorar suas 
condições econômicas. Segundo ele, os homens emigravam sazonalmente ou por períodos de vários anos em busca de renda extra, enquanto as mulheres permaneciam no comando do sítio com as crianças e o gado (VAN DE WALLE, 1975).

"Na virada do século XIX, quando a prosperidade e industrialização haviam modernizado a maior parte da Suíça, o Ticino era descrito como uma região bastante pobre e atrasada" (VAN DE WALLE, 1975, p. 448) 7 .

A terra do Ticino é quase completamente coberta de rochas. Portanto, estéril. A montanha esmaga tudo. O habitante tem de viver com muito pouco: tradições e o milho lhe falham. Da fertilidade italiana e da atividade helvética recebe só fragmentos, sua região está no rodapé da história italiana e da suíça também. A principal característica das encostas meridionais dos Alpes é seu extremo aclive. Elas não oferecem terraços com pastos montanhosos, mas penhascos púrpuras que abruptamente desabam em estreitos vales e gargantas. Chuvas torrenciais causam constante erosão, e enchentes são comuns. Quando não estão inundados, os magros pastos são queimados pelo sol ou pela geada ${ }^{8}$.

As famílias, portanto, tinham de se adaptar como podiam a essa condição econômica difícil, tal como retirantes em sua própria terra. Essas situações de pobreza e miséria são vistas em Tempo di marzo de forma menos dramática que nas narrativas "cruas" e predominantemente historiográficas de Plinio Martini (autor dos Grigioni, região que era a mais pobre dentre as pobres da Suíça italiana, apesar de ser politicamente independente), mas estão presentes em certas falas de Nino.

Aqui, portanto, a pobreza é vista pelos olhos da criança, que ainda consegue enxergar o lado bom e lúdico de sua situação, pois, na verdade, a necessidade exige que os pais façam sacrifícios...

\footnotetext{
7 Tradução nossa. At the turn of the twentieth century, when prosperity and industrialization had already modernized most of Switzerland, Ticino was described as a very poor and backward region.

${ }^{8}$ Tradução nossa. Ticinese land is nearly completely covered with stones. Therefore it is sterile. Everything is crushed by the mountain. The inhabitant must live on very little: traditions and corn fail him. From the Italian fertility and the Helvetic activity he receives only fragments, his country is on the fringe of Italian as well as of Swiss history. The principal characteristic of the southern slopes of the Alps is their extreme steepness. They do not offer terraces with mountain pastures, but barren purple crags falling abruptly into narrow valleys and gorges. Torrential rains cause continual erosion, and floods are common. When not inundated, the meagre pastures are burned by the sun or the frost.
} 
E mi tornò in mente una ragione della mamma a proposito d'una certa pietanza di magro, alla quale ella dava il nome festivo di frittura.

- Ma, mamma! è fatta di farina la tua frittura. Di carne non c'è nemmeno l'ombra...

- Eh! rispondeva: - è buona sí o no? Dunque non importa di cosa sia fatta. (CHIESA, 1984, p. 228)

Essa questão da falta de recursos na narrativa será o impulso inicial da obra. No livro, o garoto é levado pelo pai ${ }^{9}$ a um vilarejo próximo, denominado Castelletto. Apesar de ser também rural, o local já contava com maior estrutura, em comparação à “aldeia" de Vico, onde moravam, e o garoto rapidamente o "conquista" (CHIESA, 1984, p. 49).

E così mi misi prontamente sotto gamba il paese. Conoscevo ormai tutti e non solo di faccia e di nome, poiché la Tecla e lo zio facevano un gran chiacchierare, ogni giorno, degli affari di tutto Castelletto, principalmente durante i pasti... Venni cosí a sapere vita e miracoli di tutta la popolazione: e che il signor sindaco, con quella sua superbia, ha la casa coperta di ipoteche; e che l'oste d'Invalle ha l'abitudine di lavarsi solo a Natale ed a Pasqua; e che la signora Barbara, la bottegaia, ha ricevuto ier l'altro uno schiaffo in pieno viso da quella diavola d'una Cecca per una questione di galline; e che il signor prevosto, Vergine santa! Porta sotto la tonaca una biancheria cosí lisa, certe camizie, certe mutande che non le vorrebbe nemmeno il Tonio Binda...

Como que numa descoberta imprevista, infantil e mágica, detalhes dos pequenos códigos se descortinam nos falares dos habitantes de Vico, Castelletto e outros vilarejos, e, num contexto de ficção, nos são mostrados.

Ou seja, poderíamos classificar Tempo di marzo como uma ficção de transposição histórica de sua terra, a Suíça de língua italiana. Os lugares e paisagens recém-revelados oferecem, ao mesmo tempo, renovada curiosidade ao leitor, que faz com que queiramos chegar até a última página, e tensão à construção e desenvolvimento narrativo, à medida que ele se defronta com situações de um quotidiano em um lar do tio que passa a ser o seu, e em certa medida também o nosso, sob os olhos do menino e a pena do escritor.

As personagens possuem nomes ligados ao universo romano. Por exemplo, o tio em cuja casa passará a residir por um bom tempo, após a saída inicial de casa, se chama Zio

\footnotetext{
9 “Il babbo ripartì subito dopo pranzo lasciandomi pieno d'una così grave melanconia...” (CHIESA, 1984, p. 34)
} 
Roma. Esse fenômeno apelativo talvez seja mais que uma coincidência, haja visto o nome dos irmãozinhos. A menina se chama Antonina Pia. Os pequerruchos, entao, "Momo" e "Memo", na nomenclatura carinhosa e abreviada ${ }^{10}$ das crianças. Seja como for, o leitor permanece no suspense quanto ao prenome do jovem protagonista de Casa Maffea.

Mesmo com todas as aventuras e estripulias, Nino, em determinado momento, sente saudades de casa. Dramatiza, lógico, sua condição de saída forçada como se fosse uma espécie de "exilado" na casa do Tio Romualdo (CHIESA, 1984, p. 51).

Ah, dunque era stabilito che io dovessi rimanere in esilio finche gli Americani fossero partiti! La cosa mi parve ingiusta e offensiva benché, come ho detto, la vita di casa Roma non mi dispiacesse; tutt'altro! E mostrai, credo, una faccia così ammusita, che lo zio se ne accorse e stimò di dover farmi una predica sul serio.

O Zio Roma vê seu sobrinho afetuosamente, mas o considera pobre de formação, e implicitamente culpa a família do cunhado pelo fato de o menino haver tido uma educação "rústica" (CHIESA, 1984, p. 48):

- Insomma, figliuolo caro, è così. I tuoi dodici anni li hai compiuti, se non sbaglio: e a dodici anni, si può capire la ragione, che diavolo! Dunque stammi attento. Io ti tengo qui volentieri: sei figlio di una mia sorella: sei un ragazzo non cattivo, quantunque... Ma non è colpa tua se, in fatto di educazione, lasci un poco a desiderare. Insomma, casa mia à casa tua; quel che mangio io, mangi anche tu; aria buona ce n'è anche a Castelleto; e, quanto agli studi, dicevo appunto ora, me ne occupo io... Però ti voglio dire, che non sono venuto io a cercarti. È tuo padre che ti ha menato qui, che mi ha supplicato di tenerti qui, finché riuscirà a togliersi di casa quella gente d'America.

O garoto Nino, protagonista da história, inicialmente sofre, pois tem de abandonar seu quartinho de criança e ir morar com o tio "desconhecido". Conduto, ele, como a maioria das crianças, possuía grande curiosidade e capacidade de adaptação (CHIESA, 1984, p. 48):

\footnotetext{
${ }^{10}$ Abreviaturas de Rômulo e Remo.
} 
Ma, passati due o tre giorni, m'ero sentito già a tutto mio agio: le campane di Castelletto non mi facevano più fastidio; la casa dello zio mi lasciava andare e venire come si ci fossi nato. Il terzo giorno, immaginatevi! Salii sul tetto: ciò che è il massimo della confidenza che uno si possa prendere con una casa, come sarebbe, trattandosi d'una persona, salirle a cavalcioni sul collo.

Com esse recurso, Chiesa faz com que se coloquem em movimento eventos e circunstâncias "desconhecidas e novas", que, ao mesmo tempo em que farão o garoto crescer, paralelamente aumentarão nosso próprio conhecimento (e valem aqui todas as ressalvas sobre a transposição lírica da realidade, etc.) da própria Suíça italiana de antigamente.

De fato, o paese é minúsculo. No trecho seguinte (CHIESA, 1984, p. 22), temos uma clara noção do tamanho da vila de Vico - supomos que em uns dez minutos, no máximo, seja possível atravessá-la.

E via tutti a galoppo verso la stalla, ch'era lontana un cinque minuti, all'estremità del paese. Un gruppo di persone stava dinanzi alla porta spalancata della stalla; altrettanti dentro. Ci facemmo strada, senza complimenti, tra quei curiosi.

O motivo de toda a comoção: "La nostra Rossa, la nostra bella vacca fresca, senza difetti, che ci dava come niente quindici litri di latte al giorno, la più magnifica vacca di Vico e dei dintorni, stava per morire." (CHIESA, 1984, p. 22).

O animal é descrito como o mais magnífico não só da vila, mas de todos os povoados vizinhos juntos. Nino se emociona com a cena e a reação do tratador (CHIESA, 1984, p. 22 e 23):

\footnotetext{
- Rossa! povera, povera Rossa! - ripeteva senza tregua il Birgum, accarezzando la vacca con quella sua manona ruvida come un ceppo.

S'era inginocchiato accanto e le veniva facendo lunghe delicate carezze sul collo, sulla schiena e non cessava di chiamarla, con una voce così dolce, così piena di dolore, che io pure mi sentii nascere nel petto un subbuglio e ce ne volle per contenere il pianto che scoppiava.

- Rossa! Povera la mia Rossa...

E piangeva davvero il Birgum ${ }^{11}$.
}

$11 \mathrm{O}$ servente Giosuè, um bergamasco. Em "L'Albero degli Zoccoli" (filme de época produzido pela RAI em 1978 que retrata a vida dos camponeses da região de Bergamo) é mostrada um cena muito semelhante sobre uma vaca prestes a morrer, quase que uma transposição ao cinema do retrato original de Chiesa. 


\subsection{Deslocamentos e emigração}

No texto de Tempo di marzo é apresentada ao menino a figura do tio Aristide (CHIESA, 1984, p. 18), que é o irmão mais novo do signor Andrea. O garoto registra a ira do pai, como que para nossa ciência também, diante da enormidade dos iminentes fatos e sobretudo as amargas lembranças dos tempos de pronunciada carestia do passado, época essa que acreditava já superada (CHIESA, 1984, p. 11).

Ah! Vuol tornare a casa, dunque! - diceva masticando. E ci guardava con una ciera, che pareva ce ne avessimo colpa noi - A casa vuol tornare! Come se non avesse portato via tutto quel poco di buono che c'era e lasciate le croste!...

Esse sentimento é registrado pelo garoto, que percebe o olhar diferente do pai, ainda amargurado pelos sacrifícios que a família toda tivera de fazer de modo a financiar a viagem do irmão à América, em busca de fortuna.

O pai continua sua cantilena a respeito do tio:

Un giorno dice: "Vado in Russia". "E tu va in Russia; va magari al mondo della luna." "Ma ho bisogno d'un po' di denari, subito, per l'avviamento. Un'occasione magnifica. Fra dieci anni, sono milionario!...” (CHIESA, 1984, p. 11).

De volta à sua terra, falido e sem grandes honras ou conquistas, o tio tem uma dura acolhida no retorno. Seu alento é a companhia do sobrinho, que o "idolatra", enquanto o irmão e principalmente a cunhada, que se queixa sobretudo da esposa, uma estrangeira, querem vê-lo partir o quanto antes.

O senhor Andrea, pai do garoto, tinha dificuldades em "repatriar" o irmão à América do Sul por questões de tradição e também legais, ligadas ao sistema de herança partilhada, que, segundo os estudiosos, fazia com que os ticinenses tivessem grande apego à sua terra. Podiam até imigrar durante vários anos, mas quando possível, evidentemente, retornavam de modo manter o direito de seu lote, que já era bem fracionado, mas era alguma coisa. 
À primeira vista, se poderia conjeturar que o Ticino era tão pobre e propício à emigração quanto regiões tradicionalmente menos afortunadas da península. Contudo, aqui se deve fazer uma importante distinção. Na Suíça italiana as famílias tinham poucos filhos, uma vez que pouco adiantavam numerosos braços na agricultura, devido à falta de terras planas, férteis e aráveis (VAN DE WALLE, 1975). Haviam poucas opções além da agricultura e estas eram talvez até mais penosas.

Em uma passagem de Tempo di marzo, zio Rístico comenta ao sobrinho que, quando jovem, seu pai (o avô do garoto) incentivara-o a tomar a profissão de "calderero", "oficio puerco", em seu espanhol misturado com italiano. Ele, como observamos, descreve seu exfuturo chefe como um verdadeiro tirano e a profissão, em termos pejorativos e degradantes, no vernáculo que adquirira durante suas andanças no Paraguai e Argentina.

Tal como ocorre em casos reais e documentados de influências e trocas lingüísticas em comunidades de imigrantes, os anos passados na América do Sul também influenciaram o tio Rístico. Apesar dos vocábulos estrangeiros, o menino, mesmo sem entender tudo, acha bastante graça, um divertimento, uma novidade em seu universo, esse plurilingüismo do tio. Diálogos como o seguinte servem para dar mais cor, ritmo e espontaneidade narrativa à personagem (CHIESA, 1984, p. 27): “-Oh-disse - muciacio! Finirai domani di aprender l'offisio del calderero. Offisio puerco. Vamos a passegiar".

Exposto a diferentes culturas durante suas andanças pela América, o tio percebe bastante claramente os costumes locais, que, num acesso de ressentimento, classifica de pequenos, retrógrados, mesquinhos. Esse estranhamento, essa noção de ser estrangeiro em sua própria terra natal fica evidenciada no trecho a seguir (CHIESA, 1984, p. 27):

Paese meschino! - conchiuse - usanze miserabili. Nessuna abbondanza di idee.. Hai sentito muciacio, un'ora fa, che bordello in casa tua per una straccia di vacca andata al Creatore? Una vacca! Nella Pampa, le vacche si contano a cento a cento, a mille, a mille. Cade un fulmine, ne ammazza trenta, quaranta e nessuno se ne accorge. Quelli son paesi! 
Nota-se aqui a descrição hiperbólica! Talvez um trocadilho bem-humorado de Chiesa consigo mesmo ${ }^{12}$, sobre a imensidão e abundância dos Pampas argentinos, na voz do tio, que diz que um raio é capaz de liquidar trinta, quarenta vacas, e que esse fato não preocupa ninguém (ao contrário de Vico, onde a morte de um velho bovino gerara uma verdadeira comoção em sua família, que era bastante humilde e contava com o leite do animal), pois existem centenas, milhares de outras. Conclui com uma ponta de nostalgia, afirmando: “Aqueles é que são lugares bons!” (CHIESA, 1984, p. 27)

O menino, entristecido com esse novo conhecimento adquirido, esse se aproximar mais da adolescência e deixar a infância, faz então a direta e dolorosa indagação (CHIESA, 1984, p. 27):

Ma zio - dissi un po' risentito - e perchè non ci torni dunque? - Parole di tua madre! - sentenziò. Ma no, zio. Anche la gente del paese lo dice. E dice che...

Isso deixa o senhor Aristide sem ação por um momento, como que rememorando sinteticamente a experiência vivida no estrangeiro. Ao final, ele acredita que o menino, por si só, não seria capaz de elaborar isso tudo.

A seqüência do diálogo nos mostra claramente a incompreensão do tio em relação às fofocas do povo daquela vilinha de interior, recolhida em seu próprio mundo, seu próprio aquário. Ironicamente, ele se refere a essas pessoas como “o povo com 'pê' maiúsculo de Vico", em uma tradução idiomática (CHIESA, 1984, p. 27):

- Oh, sentiamo cosa dice la maiuscola gente di Vico!

- Dice... - risposi facendomi coraggio - dice che in questo paese tutti vanno a messa la domenica, e tu no. E che il vostro bambino non lo avete nemmen battezzato... E che la zia Clotilde ha scritto una lettera al papa per dirgli che lei rinunziava alla religione.

${ }^{12}$ É de Chiesa a expressão "República da Hipérbole" (repubblica iperbolica), publicada em suas Lettere iperboliche. cfr. CALGARI. 
O topos da falta de recursos e condições financeiras está presente ao longo da narrativa. Por exemplo, quando finalmente o tio parte, deixa dividas de bebida. O babbo tem uma acalorada discussão com a mamma (CHIESA, 1984, p. 90-91).

Il babbo stette un poco a rimirarla tutto benigno; poi le mise una mano sulla spalla: - Sempre di malumore la mia sposa! - esclamò; - sempre la luna di traverso. Ma se lo dico, io! Difficile cambiar la testa dei cristiani. Se fosse come questa qui...

- Se ne comperava una nuova.

- Ben detto.

- E la si paga tre, quattro franchi.

- Non è la fine del mondo!

- Difatti. Però quattro franchi sommati con questi fanno cinquantaquattro.

Così dicendo, la mamma si levò di tasca una cartaccia spiegazzata, con su dei numeri.

Em contraste com essa realidade de pobreza, está a natureza da região, que Chiesa

(1971, p. 176) nos apresenta como se conhecessemos pessoalmente suas fontes, suas árvores, seu característico brilho de Sol.

I butti d'acqua che venivano giù dalle docce delle fontane, bisognava per forza che li toccassi, tanto mi sembravano incredibili. E il sole! Quel bel sole d'oro biondo, morbido e buono come se mi conoscesse personalmente, non mi bastava di vederlo luccicare sulle cortecce violette degli alberi, né pure de sentirmelo sul dosso delle mani, che gli stendevo, divenute lunghe e bianche da non riconoscerle piú. Bisognava guazzare, in quel sole! Far come le oche, di maggio, quando si gettano agitando le ali nel fitto d'una grande acquata. 


\subsection{Referências às instituições locais}

Ocorre um surto de varíola em Vico, que faz com que a escola primária seja fechada indefinidademente. Tais epidemias eram comuns no início do XX e constituiam um perigo mortal às pessoas. Nino, que é um menino, imediatamente vê o lado positivo da situação, acha "excelente" a idéia de que tiveram de fechar, por precaução, a escola. Ele, quer estar do lado de fora, brincar pelos prados, riachos, campos e montanhas de sua terra. Porém, a obrigação de fazer lição de aritmética ou italiano o chama. (CHIESA, 1984, p. 1)

Ma proibito uscire: due o tre giorni prima era morto di vaiuolo un ragazzetto del paese; un altro si trovava tra vita e morte e avevano chiusa la scuola. Ottima idea questa, ma guastata dal divieto di andar per i fatti proprii e dall'obbligo (almeno in casa mia) di eseguire ogni giorno un lavoro d'italiano o d'aritmetica.

Aqui temos a língua materna da terra de Chiesa registrada num âmbito ficcional. Talvez uma espécie de diálogo entre o Zio Franceso educador e o romancista. Para Nino, a aritmética não passa de um alegre jogo. O importante para ele é continuar a ser ele mesmo, persistir em fazer o que gosta, quando o quer, como toda criança (CHIESA, 1984, p. 1 \& 2).

- Che cos'è, in fondo, l'aritmetica? Un giuoco, e uno dei giuochi piú divertenti che siano stati inventati... Dio mio! Perduta la libertà, tutto il resto conta poco e può accadere che, senza volerlo, cosí per disperazione, si trovi un principio di divertimento nel dividere un numero per un altro e nel fare la prova.

O menino Nino inicia a como que filosofar nesta situação, onde por questão das circunstâncias precisa permanecer em um ambiente confinado, mesmo desejando intensamente vagar pelos campos, como a maioria das crianças... $\mathrm{O}$ importante é que as tarefas sejam lúdicas. 
Quando apresentada desta forma pelo professor novo, sua oposição à aritmética diminui (CHIESA, 1984, p. 158): "Quell'uggia dei numeri, da sommare, da dividere, egli sapeva trasformarcela in un giuoco niente affato noioso”.

Já o Zio Rístico, por sua vez, tem sua própria e resoluta filosofia de vida. Esse talvez seja o momento mais "adulto" de todos na narrativa de Tempo di marzo, uma passagem que poderia estar em Io e $i$ miei, que discorreremos mais adiante. Um pequeno extrato, uma anteprima, como diríamos em italiano, uma espécie de prenúncio daquele tom amargurado, ácido, que convencionamos a chamar de "moderno".

Quaisquer possíveis certezas metafísicas ensinadas a Rístico em seu catecismo infantil foram corroídas pela rudeza das viagens, pelo salitre dos portos longínquos e sobretudo pela consciência das inexoráveis perdas no percurso que é a vida. Ele, portanto, com seu italiano carregado de estrangeirismos (aora, bien, alli) tenta explicar ao menino que ele não deveria dar ouvidos a essas velhinhas da vila, que vivem a fofocar (CHIESA, 1984, p. 28).

Aora-bien! la prima cosa che te apprendo è questa: lasciare che la gente faccia le sue parlerie. Un momento fa, siamo passati dinanzi al cemeterio: lí sta la mia sorella Lia, una testa di passero, povera donna! e fino a qui, non era colpa mia. Nel cemeterio vecchio, allí dietro la chiesa, sta mio padre, mia madre, qualche altro fratello, e zii, parenti, conoscenti in grande quantità; poiché vita nostra è come un carro di legna, che va va e va e ad ogni scossa lascia cader per istrada una fascina...

Notamos aí o uso da palavra "istrada", assim como de outros espanholismos, etc.

Existem aqui referências notadamente à tia que o menino jamais conheceu e que é referida como uma avoada, "cabeça de vento", assim como aos avós e tios-avós. Incluem-se também outros parentes e conhecidos, o que serve para reforçar a idéia de que um dia todos irão parar no cemitério, quer seja ele antigo ou novo. 
Ajuntemos a isso, paradoxalmente, a imagem resignada do carro de madeira, que simboliza, em vez do acúmulo durante a vida, a perda, os entes queridos vão caindo pelo percurso e jazem no chão. Até que sejam levados ao cemitério, à igreja.

Em um registro também em vestes de adulto, agora na voz do próprio narrador confundido talvez com o autor, ele explicita que nesse momento não é mais a personagem Nino que está a falar, e sim talvez um Chiesa autor, defensor do patrimônio histórico e cultural, que nos proporciona uma descrição arquitetônica bastante técnica e pormenorizada de uma igreja de Ticino.

Esse conhecimento referente aos monumentos principais da origem italiana de sua terra era para ele questão de orgulho, e existe essa comunicação com sua obra ficcional aqui em Tempo di marzo (CHIESA, 1984, p. 67):

La chiesa di Castelletto (per parlare da persona istruita ) è un edifizio a tre navate, con due ali di tetto piú basse, fra le quali balza su, grande e grosso, il corpo di mezzo, come un pretone quando recita il confiteor appié dell'altare, fra i due chierichini inginocchiati. Uscimmo dunque sul tetto, risalimmo gatton gattoni il pendio di lastre scottanti abbaglianti, fino al muro, alto due uomini almeno. Su, su, sotto la gronda, s'apriva una finestrellaccia buia, che il mio amico m'indicò con un bel sorriso dicendo: - Ormai siamo arrivati.

O seminário era uma das escolhas possíveis, por assim dizer, aos garotos da idade de menino. Observemos o trecho seguinte (CHIESA, 1984, p. 250):

Dunque è vero - mi chiese ad un tratto l'amico - che anche tu vieni questo novembre in seminario?

- Ma che! - risposi subito. - Chi t'ha detto questa frottola.

- Ma? ... Ho sentito dire...

E non fu possibile cavargli una parola di più. "Io prete?...", rimuginavo. "Come mai possono aver inventata una fandonia simile? Fra quindici giorni rientro in collegio; subito dopo la prima settimana d'ottobre."

O menino sabia que teria que retornar ao colégio... (CHIESA, 1984, p. 250)

Già il babbo, la sera prima, aveva annunziata l'antipatica data. - Bisognerà preparare le cose di questo ragazzo - aveva detto -, perché oggi quindici, al più tardi, si torna a Borgovecchio. 
Ele se insurge, então, com súbitas e conscientes, firmes explicações doutrinárias referentes à necessidade de se ter realmente manteiga na sopa. O garoto está se tornando adolescente, percebe os "jeitinhos" que seus pais dão, as adaptações necessárias de modo a sobreviverem (CHIESA, 1984, p. 250).

Lí per lì, non ci avevo fatto gran caso, occupato com'ero dai pensieri affannosi di quei giorni e malcontento della mamma la quale (erano le tempora d'autunno) non aveva abbastanza burro per condire la minestra, aveva buttato nella pentola una pestatura di lardo...All'obbligo del magro si obbedisce o non si obbedisce, perbacco! e una via de mezzo non esiste... E quasi mi compiacevo di abbandonar presto quale nostra mal governata casa, dove si tenevano discorsi così sconvenienti e si passava sopra ai precetti della Chiesa con tanta disinvoltura.

No trecho abaixo, Chiesa descreve com precisão os fenômenos metereológicos. Aos talentos do prosador, aqui somam-se os do poeta. Sentimo-nos como se fossemos o Nino, uma doce sensação de vaguejar pelos campos e bosques suíços, como que momentaneamente disperso da preocupação que o aflige. Teme, em suas palavras, "reperder" a liberdade. Ou seja, teria que voltar à escola. Por isto, questiona o amigo sobre o calendário do seminário, sem perceber, num primeiro momento, que esta talvez fosse uma instituição até mais rígida que sua escola. (CHIESA, 1984, p. 250 e 251)

Ma quella mattina (colpa del sole, che era venuto spiegandosi fuor dalla nebbiolina rosa con una gioia spropositata? ...colpa di quel pretino che aveva indosso un odor di campagna cosí forte e buono. Quella mattina, a ripensar che fra quindici giorni avrei riperduta la mia dolce libertà mi sentii struggere il cuore. - Dunque - dissi, riavvicinandomi all'amico - in seminario si rientra il mese di novembre?

- Per San Carlo, giorno quattro novembre.

Talvez antecipando a desilusão que sentiria com a experiência no seminário,

metaforicamente, observa o estado da túnica. Com o tempo, tudo passa.

Dopo un paio di mese di vacanza, il povero abito talare s'era ridotto a condizioni nn liete. E sfido io! con tante siepi da traversare, con tutta l'acqua che Dio manda e tutta la polvere che il vento porta, con tutti gli usi cui può servire un bel pezzo di stoffa sempre lì pronto, come avviluppare cose, pulire mani, spegnere incendi... Ebbene, chi lo crederebbe? quegli sbrendoli quelle macchie, quelli occhielli sconquassati, quel coloro ne di te né di me, mi fecero l'effetto d'altrettante cose amiche, le quali mi gridassero ciascuna la sua brava parolaccia simpatica. 
Existe a noção da aproximação do quotidiano com a menção abaixo do dialeto, que era falado na família, mas também considerado um falar "rústico", na época (isto é, antes das relativamente recentes ondas de "redescobrimento" desses falares regionais de ambos lados da fronteira política) (CHIESA, 1984, p. 251).

Finche nuova, la tonaca dell'amico parlava latino e mi dava soggezione: ormai, s'era messa a parlare nel dialetto mio piú rude, e mi diceva le sue ragioni sacerdotali senza darsi piú nessuna aria. - Ma sí - diceva - fatti prete anche tu. Vedrai. Non é poi la fine del mondo!

Nesses vilarejos alpinos, assim como nas cidadezinhas da península, as igrejas desempenham importante papel de referência geográfica e cultural. Quanto ao estilo, notamos o emprego de diminutivos e aumentativos, no estilo das crianças, que reforçam a infantilidade da "voz" de Nino. Notamos na passagem abaixo (CHIESA, 1984, p. 45) o emprego de vocábulos como "muruzinho", “fachadona”, “janelona":

Lo zio si sedette sul muricciulo e si mise a leggere il giornale. E anch'io mi sedetti e rimasi un poco a guardare quella facciatona pretensiosa della chiesa, quelle due barbacce di santi sporgenti dalle due nicchie, quella finastraccia, sopra la porta, che aveva un fare di superbia fuori di posto, quelle righe di sporcizia che venivano giú senza vergogna, come se avessero ragione loro... E dissi:

- Zio, è una chiesa del medio evo questa, nevvero?

Lo zio mi volse di sbieco un'occhiata allegra.

- E perché dici che è una chiesa del medio evo?

- Perché è brutta.

As interações entre o garoto do cantão de Ticino da virada do século XIX e as outras personagens, seus diálogos (em italiano padrão, mas com algumas expressões italianizadas, vindas do dialeto), fazem com que percebamos, progressiva e seguramente, que estamos diante de uma cultura singular, aquela da Suíça de língua italiana. 


\section{Capítulo terceiro}

\section{RETRATO DE UMA FAMÍLIA ATUAL EM IO E I MIEI}

\subsection{Contraste com Tempo di marzo}

Tempo di marzo é o romance do externo. A ação se passa em sua maior parte do lado de fora, vista pelos olhos de Nino. O mundo da narrativa é portanto palpável, recheado das descrições proporcionadas pela já comentada destreza técnica do autor em pintar os fenômenos da natureza.

Io e $i$ miei, por outro lado, apesar de mostrar cenas externas, como a da subida à montanha de Manlio (que comentaremos mais adiante), é um e sobretudo um contar remoído das profundas dúvidas e tormentos psicológicos do protagonista, o pater familias.

Após sessenta anos de seu lançamento, Io e i miei continua atual. Aqui, a temática idílica e de identificação regional com a natureza, tão presente em Tempo di marzo, é substituída por um pessimismo lânguido, uma sensação de inevitabilidade e de torpor tão fortes, que por vezes nos perguntamos se é realmente o mesmo autor que compôs as duas obras! Este é de certa forma um livro que foi "filho" da guerra. Foi publicado em pleno conflito mundial, em 1943, pela Mondadori, sem as revisões de praxe do autor, que era famoso por seu perfeccionismo e atenção aos detalhes.

É como se encontrássemos um Chiesa mudado, "ao contrário" de seu percurso normal. Portanto, com este pensamento em mente, discorremos a seguir sobre a recepção que a obra obteve. 
Republicado quase trinta anos mais tarde, na Páscoa de 1973, a poucos meses da morte de Chiesa, que já estava com a espantosa idade de 101 anos e ainda ativamente revisava suas obras, o prefácio da edição suíça expressa a idéia de que o livro provavelmente teria obtido maior repercussão entre o público e a crítica italianos. É sobretudo uma obra anômala, pois "moderna" dentro da estética chiesiana.

Enquanto Tempo di marzo é uma leitura leve e alegre da meninice, Io e i miei é como que um convite à depressão crônica, à renúncia da menor possibilidade de ser feliz em família. Ao final de sua leitura, ficamos de tal maneira imbuídos dessa "nova" maneira de pensar que a única observação possível, nesse "rovesciamento", mesmo que temporário - pois o mundo continuaria após a guerra, assim como o Chiesa literário persistiria após o desaparecimento do poeta nesse mesmo ano de 1973 -, é que o prefácio livro se tornou uma espécie de testemunho à sua modernidade após a leitura. 


\section{A V VERTENZA}

Io e $\mathrm{i}$ miei apparve primamente presso la casa Mondadori di Milano nel settembre del 1944. La data gia di per sé molto dice al lettore: si andava verso lo scorcio della guerra, per l'Italia settentrionale dolorosissimo e greve di minacce; e ferreamente chiusa ogni frontiera. Di qui una noticina editoriale: "Questo volume fu licenziato per la stampa senza alcuna revisione delle bozze da parte dell'Autore, al quale la Casa Editrice non poté farle pervenire». Di qui, anche, la scarsa o nulla eco che l'opera ebbe in giornali e riviste.

Questa nuova edizione, a distanza di quasi trent'anni, da modo all'Autore di eliminare alcune piccole imperfezioni tecniche $e$ di accordare insomma quel «buono per la stampa) che le circostanze belliche di allora non avevano potuto consentire.

Figura 3 - Io e i miei, prefácio da Editora Cantonetto (abril de 1973)

3.2 Loucura, personificação e melancolia

O tema da loucura está presente em Io e i miei. A própria esposa do protagonista o vê com apreensão, a medida que percebe que seu intuito de realizar uma espécie de diário dos acontecimentos de sua família, o leva a buscar a tranqüilidade (na interpretação do marido) de habitar em um cômodo separado. Esta atitude primeiro ela julga excêntrica e depois, diante da inevitabilidade dos fatos, se resigna. 
O narrador nos mostra em um registro irônico e sarcástico de si mesmo que dá razão, parcialmente à mulher. São elencados exemplos próprio se julga louco, ao citar exemplos deste suposto veio de insanidade que percorre sua família, onde quatro dos dez filhos, ou seja, praticamente a metade, é composta de figuras excêntricas (CHIESA, 1973, p. 12).

Perché mia moglie ha sempre nascosto in fondo, all'animo un vago timore che, nelle vene di suo marito, circoli qualche stilla di follia. Non credo che sia timore fondato, quantunque nella mia numerosa famiglia (dieci tra fratelli e sorelle) ci siano stati effettivamente alcuni personaggi un po' fuori del comune; un giramondo, un rabdomante, una santissima monaca ed un innocente che vive ancora nella nostra casa patema lassù in montagna, tutto roseo e felice.

Ao transportar o exemplo da família a si mesmo, admite que suas atitudes também são pouco convencionais. Elenca uma série de patologias que isoladamente descrevem a dificuldade de certas pessoas em estarem satisfeitas com aspectos de suas vidas. Nesta espécie de monólogo interior, admite a si mesmo que sua maneira de ser e enxergar o mundo pode ser considerada peculiar (CHIESA, 1973, p. 12).

È pure innegabile che il mio carattere non coincide perfettamente con lo schema più comune; che il mio modo d'intendere e di prendere la vita può sembrare alquanto singolare. Il mio polifilismo soprattutto. Io conosco uomini (disgraziatissimi uomini, a mio avviso) i quali non riescono ad amare nulla; né la loro casa, né il loro mestiere, né il pane che mangiano, né l'acqua che bevono: la gente li definisce bisbetici, dispeptici, ipocondriaci; non però pazzi.

Aqui temos mais uma referência direta à literatura italiana do Séc XVI, onde os conhecidos do protagonista (aquelas pessoas dispépticas, bisbéticas, etc) seriam cada qual uma espécie de Orlandos Furiosos ao contrário, loucos por que não amam, “disamorati e pazzi” (CHIESA, 1973, p. 12)

Purtroppo è cosi: gli uomini sono inclinati a giudicare meno anormale il disamore che l'amore : il disamore, nei casi gravi, sarà una malattia; l'amore, quasi sempre, una follia od una mezza follia. Non si dice forse : " innamorato pazzo »? Nessuno dice « disamorato pazzo ». 
Com o correr da narrativa, as discussões e impressões psicológicas se adensam. Se, no episódio do jardim da Sra. Lucia em Tempo di marzo havia uma jovialidade, aqui este "riso" é entristecido. O próprio pomar está enclausurado por muros altos (CHIESA, 1973, p. 66).

- Ma no, ma no ! - mi gridò la Brigida.

- Credete forse che sia una malattia da stare a letto?

Sarebbe ancora una fortuna. E mi spinse verso il giardino: quello che in casa nostra sempre an chiamato giardino, ed è ortaglia, frutteto, giardino anche; chiuso lungo tre lati da un muro piuttosto alto, e lungo l'altro da uno steccato che lo separa dal, cortile. La Brigida si tolse di tasca la chiave del cancelletto, apri e mi fece entrare, gin gin fin in fondo al viale, dove c'è quella panchetta di sasso addossata al muro, tra grandi cespi di ortensie.

Tem-se a sensação que as personagens são apáticas, espectadoras de suas próprias vidas, objetos de um inelutável destino, pois sempre amargo. O fato de se estar doente, acamado é visto como uma benção. Tem-se a impressão que a melhor maneira de se estar, é imóvel como os arbustos, em uma espécie de despersonificação, onde as conformadas personagens descendem ao reino vegetal e se tornam plantas. (CHIESA, 1973, p. 66 e 67)

Seduto su quella panchetta, stava il mio povero fratello, immobile come un ceppo, col busto pendente innanzi e le due mani schiacciate sulle ginocchia. suono della mia voce, sollevò un istante' gli occhi e li lasciò ricadere. Mi parve di sorprendervi (una traccia dell'abituale sorriso; ma quando, al mio ripetuto richiamo, raddrizzò il volto, m'accorsi che quella sembianza di riso risultava da uno strizzamento delle palpebre, da un raggrinzamento della pelle sul colmo degli zigomi, e che gli occhi non partecipavano

Portanto, as raras e dolorosas reações autônomas do irmão, com o qual ele irá se encontrar em um cemitério, que faz vez de manicômio. Mesmo imbuídas de imensa dor, as pequenas reações do irmão são vistas como uma espécie de vitória, daquilo que ainda resta de humano sobre o processo de petrificação interior que se abateu sobre ele. Como que se acometido de um irrecuperável câncer da alma (CHIESA, 1973, p. 67 e 68).

Era là, aggrappato alle sbarre del cancello chiuso. Gli tocai le spalle; e lui, come se sentisse nelle mie dita quando mi batteva il cuore, si volse con una faccia che allora sì, solo allora, parve riconoscermi. Quel brutto ridere degli zigomi s'era sciolto; e gli occhi, pieni d'un tremante dolore umano, mi guardavano supplichevoli, come invocando pietà e protezione. 
No sentido inverso, temos o movimento dos objetos, que a tornam-se maiores que si. Até a própria casa antiga, é personificada. Percebemos a sensação de tristeza, melanconia, como se fosse um ser abandonado e rejeitado... (CHIESA, 1973, p. 67)

"La mia vecchia casa, che non rivedevo da parecchi mesi, m'accolse con il suo sorriso buono, un po' melanconico. Ma questa volta, più che melanconia, era una tristezza, pura tristezza, che nemmen tentava di dissimularsi. Come se mi dicesse: $<<\mathrm{Oh}$, eccoti! È proprio necessaria una disgrazia perché tu ritorni?>>"

Mesmo em momentos que deveriam ser supostamente felizes na história de uma família, como o noivado ou expectativa de um casamento, esta etapa é interpretada pela ótica "experimentada" do viúvo, já em seu segundo casamento pleno de amarguras, renûncias e resignações. Em uma situação 'normal', ele e os seus estariam alegres com a notícia do noivado. Mesmo que houvessem dúvidas quanto a sua sustentabilidade financeira, o futuro profissional do noivo, estas seriam prontamente diluídas pela expectativa de uma bonita e jovial nora, que viria a trazer alegria, espécie de feliz contrapeso a sua tão singular família.

Quando, ao invés disto, percebe que seu filho Manlio deseja se esposar com uma senhora já de idade avançada, isto lhe ferve o sangue. Aqui, está em jogo mais que a idade e expectativa 'normal' de se ter netos e sim o caráter da senhora Falkenhaus. Considera o filho ludibriado, espécie de vítima da loucura do amor (CHIESA, 1973, p. 150).

Che un giovinotto come Manlio: sano, bencostrutto, ventiquattr'anni, pensi di sposarsi, è più che giusto e naturale; e nessun padre ragionevole si meraviglia a una notizia cosí. Potra, sí, in certe casi, osservare: $<<$ Ma, figliuolo: e il tetto per quando piove? E il pane? E il resto?... >> Io, nel caso mio, avrei potuto chiedere, in forma piu determinata: $<<$ Manlio, sai dirmi quanto ti renda il tuo mestiere di cronista nel nostro massimo giornale cittadino? Hai un'idea del minimo che occorre ad una famigliuola anche modesta?... >> Ma obbiezioni simili si fanno quando nulla c'è da ridire sul resto. Io, invece, all'udir il nome di quella signora Falkenhaus, m'ero sentito coagulare il sangue... 


\subsection{Personagens espectrais}

Transparece pelo escorrer da narrativa que até mesmo a mulher, que a princípio havíamos julgado mais equilibrada e racional que o marido, possivelmente sofre de algum distúrbio psicologico. Conforme já observado, ele é dado a manias e excentricidades. Ela, por sua vez possui, ou melhor é tomada por uma 'paura' de que os mortos voltem à vida, que assombram e rondem sua casa.

"Già, la mia brava, sensata moglie crede che la zia Susanna riviva, o tenti di rivivere nei panni della nostra Serafina. Perciò tratta quella povera morta col risentimento che di solito dedichiamo ai vivi” (CHIESA, 1973, p. 44).

"Stasera la Serafina dice: - Mi è venuta un'idea. Il piano non mi dice più nulla. Vorrei prendere lezione di violino." (CHIESA, 1973, p. 113)

O que seria uma simples vontade de moça prendada, ou talvez inocente coincidência, de se aprender a tocar um instrumento musical, torna-se algo muito mais complexo, devido ao histórico da família e o próprio modo de raciocinar de sua mãe, que já antecipa o pior e tem um verdadeiro acesso de fúria irracional: “ - Ah, questo poi no! - fa la mamma con una faccia piena d'ira e di spavento. - No, e poi no! Vuoi dunque diventare il ritratto perfetto di quella disgraziata?" (CHIESA, 1973, p. 43)

Temos aqui, portanto, a presença de uma personagem espectral na narrativa. Io e miei, escrito em 1944, enquanto os países circundantes eram destroçados pela guerra, nos faz sentir, no retrato "terreno" desta unidade familiar"13.

Uma obra, portanto, eminentemente contemporânea em seus elementos narrativos e que, ao contrário da beleza idílica e localizada, identificada com o Ticino da obra poética e do

\footnotetext{
13 Observamos que Paolina, filha do primeiro casamento do Signor Andrea, que fugiu de casa sem dar notícias funciona como personagem espectral na narrativa de Tempo di marzo. "Mi sentivo tutto commosso; e tra un boccone e l'altro, lanciavo un'occhiata al babbo. Era smorto, abbaruffato, teneva la faccia sul piatto e non diceva nulla. Il segno di quella sua antica ferita gli faceva sulla fronte pallida un grosso sgorbio color vino. Voltava e rivoltava con la forchetta quei quattro gnocchi che s'era presi giù e pareva che non sapesse rivolgersi a metterne in bocca uno" (CHIESA, 1973, p. 100).
} 
próprio Tempo di marzo, possui uma 'amargura' que continua bastante atual, uma acidez no relato e na profundidade narrativa...

Sentimos sempre uma ânsia, um esforço sendo feito pelas personagens. A liberdade que é buscada a duras penas.

Il piccolo sforzo che occorre a buttar le gambe fuori del letto è sempre press'a poco lo stesso, qualunque l'ora; e quel trovarmi in piedi mentre fuori è ancora buio e in casa tutti ancora dormono, mi procura non so quale soddisfazione, un senso di via libera, direi. E mi piace uscire adoperando una chiave del mio mazzo, richiudere con una chiave mia". (CHIESA, 1973, p. 135).

\subsection{Diálogos com Il fondo del sacco}

A medida que o pai comenta sobre os temas jornalísticos mais terrenos abordados por Manlio (CHIESA, 1973, p. 164), nos lembramos aqui do Signor Andrea, pai de Nino, o agora famoso para nós, geômetra de Tempo di marzo e também, do próprio autor, que bem poderia, grande estudioso e catalogador da arte e arquitetura de origem italiana de sua terra...

Da qualche tempo, Manlio s'è alquanto svincolato dalla letteratura pura e scrive articoli su argomenti terrestri, problemi che toccano la vita del paese: il nostro solo, la nostra gente... Un suo articolo della settimana scorsa raccontava un'escursione, non so se vera o immaginaria, in alta montagna: ciò che egli aveva osservato in certi villaggi che vengono rapidamente spopolandosi, la tristezza delle case cadenti, dei campicelli abbandonati, dei sentieri riafferrati dagli sterpi e dai rovi.

O protagonista é inspetor florestal de profissão e como tal, conhece a fundo a natureza

e o estado de decadência de certos vilarejos e comunidades da região (CHIESA, 1973, p.

165).

Invece è un povero villaggio che sta morendo; se pure, a quest'ora, non è morto del tutto. Io ci fui l'ultima volta dodici anni fa in compagnia d'un tale che preparava una pubblicazione sulle case tipiche del nostro paese: uno di quegli studiosi pei quali il mondo, se esiste, è per poter essere il campo delle loro ricerche. Entrava per ogni uscio come se fosse casa sua, a curiosare, frugare, inquisire, far fotografie, disegni, misurazioni. 
No registro abaixo, fica evidente em riqueza de detalhes descritivos o quadro de abandono e desolação destes lugares esquecidos pelo tempo (CHIESA, 1973, p. 166).

Passando ad una casa, ci si accorge se è viva o morta, se sta bene od è malata; ma ben altro è trovarcisi dentro, vedere e toccare nelle sue radici quel male che fuori si palesa con noti sintomi: pareti spelacchiate, vetri rotti, umidità e sporcizia. Nemmeno quelle manifestazioni esterne avevo ben osservate prima d'allora.

Estão presentes os detalhes da sujeira, que nos transportam a esta realidade de pobreza e imundice, nada idílica, onde vivem estas populações, na sua maioria, de velhos. Existe um vapor de desintegração... Resta apenas imaginar como deveria ter sido formoso o vilarejo em seu apogeu, cem, duzentos anos atrás (CHIESA 1973, p. 166).

L'aspetto di quel villaggio in agonia mi si rivelò in tutta la sua tragica tristezza che il mio compagno si fermava a prendere la fotografia di quella loggia senza più sbarre, di quella gronda che lasciava prendere un pezzo di doccia, di quella povera facciata che doveva essere ai suoi tempi tutta grazia ed eleganza: certi stucchi, certi graffiti, certi davanzaletti da affacciarvisi una damina del settecento!...

Este tema do isolamento rural foi retratado por um escritor moderno da Suíça Italiana, chamado Plínio Martini. Nascido em uma remota localidade dos grisões Martini escolheu, em suas próprias palavras de uma maneira mais próxima possível à 'realidade historiográfica'. É portanto, um escritor engajado. Enquanto Chiesa possuía (conforme veremos mais a frente) um projeto "político" ligado à disseminação da língua formal, a preocupação principal de Martini era com a temática social, mais do que a do idílio e da memória. Com efeito, uma leitura de "Il fondo del Sacco" revela a crueza, os nuances de miséria e dificuldades enfrentadas pela gente destes vales e colinas remotas, perdidas no tempo e no isolamento (MARTINI, 2005, p. 96). 
Sono queste le cose che pensavo intanto che il giudice parlava: perché sono partito, perché sono ritornato, perché non posso più essere contento né di qua né di là del mare. Camminavamo su e giù per la campagna di Roseto lungo il sentiero che va dalla terra di dentro a quella di fuori. I suoi esempi erano sempre gli stessi casi di miseria disgrazie mortali cattiverie fame e impotente carità; messi insieme però facevano la storia di Cavergno; ora io non so se la storia di un paese di cinquecento anime possa avere un significato; certo l'aveva per lui. lo pensavo che quello era il mio paese, buono o gramo uscivo da quel ceppo, quelle erano le mie radici. Così ascoltavo.

Desde as intempéries do inverno e do gelo, à emigração que torna vilarejos inteiros "cidades fantasmas" ou reduto de idosas senhoras que sozinhas passam o tempo a lembrar do passado, assoladas pela fome, pela doença e sobretudo por aquela crônica e languida, resignada sensação de nostalgia dos entes queridos que foram ganhar a vida na Califórnia e jamais retornariam.

Também de il Fondo del Sacco (MARTINI, 2005, p. 95):

Io a guardarli avevo pensato a me e a Cavergno; certo quel pensiero lo facevano anche gli altri rancieri. Così subito dopo la guerra sono venuto, per trovare un paese dove non capita mai niente: il fieno, il recidivo, domani sarà bello, è caduta una vacca ai Folla, un gran silenzio. C'era da impazzire. Dopo cinque mesi ho ripreso il mare come uno che scappa e non sa più dove rifugiarsi: anche l'America non mi faceva più voglia.

Um realidade semelhante havia sido retratada por Chiesa "moderno", sem as transposições artísticas presentes em Tempo di marzo. A solidão domina o ambiente nesta passagem de Io e i miei (CHIESA, 1973, p. 166, 167).

Appunto, la gentilezza nativa di quelle costruzioni aggiungeva un senso di commovente sventura alla loro ruina. $\mathrm{Si}$ può guardare indifferenti il diroccare d'una stallacia; non una nobile parete che va in briciole. - Perché lasciate andare in malora la vostra bella casa?, - chiesi ad una vecchietta che sedeva presso la sconquassata porta. - Ma!... - sospirò. - Non c'è più nessuno. 


\subsection{O drama de CAM}

O quadrúpede Cam é o cãozinho da família, que a exemplo dos donos, vive envolto em seu próprio drama pessoal. Como se neste núcleo familiar, até o bichinho de estimação fosse atormentado pela "modernidade", no sentido da densidade da personagem e seus conflitos existenciais. Evidentemente que Cam não é um ser mágico e portanto, isento da capacidade de falar, mas a descrição da comunicação do dono faz com que por meio dele percebamos toda a personificação do sofrimento do animal "MERCOLEDÌ - Tutta la notte, ululi e pianti, il povero incatenato.” (CHIESA, 1973, p. 107)

De fato, sentimos como se uma pessoa, talvez um prisioneiro da guerra que estivesse acorrentado. O motivo disto tudo, é a suspeita de que o animal teria contraído raiva dias atrás... (CHIESA, 1973, p. 105)

LUNEDÌ - Cam, il mio belo cane lupo è tornato a casa stasera con un'orecchia lacera grondante sangue. Macchiato di sangue anche il giornale che teneva coi denti e mi porse sollevando il muso. Gli avevo detto: - Cam! Perduto... giornale... Va, cerca...

Uma descrição praticamente universal de que todos que já tiveram um cãozinho conseguirão entender. Mais a frente, existe a descrição específica do local (CHIESA, 1973, p. 105):

\footnotetext{
"Gli avevo fatto segno verso San Giorgio, il santuarietto sulla collina, dov'ero stato nel pomeriggio: probabile che il mio giornale fosse restato sul muricciulo del sagrato. - Perduto... giornale... San Giorgio... cerca...”
}

Nota-se acima a presença dos diminutivos: "santuariozinho" e "muretinha", nas palavras de um adulto, que imediatamente lembra o leitor de Chiesa andanças de Nino, em Tempo di marzo, como se o autor quisesse fazer uma referência a ele mesmo. Também importante, aqui temos uma indicação de caráter geográfico. 
A região de fronteira do Monte San Giorgio, localizado na área de Meride, em seu Mendrisiotto natal, recentemente declarado patrimônio da humanidade pela Unesco.

Ao invés de demonstrar segurança e consolar o marido, o que aconteceria talvez em um romance romântico e linear, a esposa é de tal modo insegura, que suas apreensões contaminam o ânimo do marido mais até do que a suposta mordida infecionada e infectante do cãozinho Cam: "La mia ferita non mi fa un gran male ma se ci penso, si mette a pulsare. Io, per mio contro, forse non ci penserei tanto; ma mia moglie mi ha propagato un po' della sua angoscia." (CHIESA, 1973, p.113)

Todos os medos e preocupações da esposa se condensam:

Teme, sì, che suo marito sia stato morso da un cane idrofobo. L'ho sgridata, l'ho presa in giro, le ho fatto sentire le mie cose più allegre. Ma ora che son qui solo, sento questa mia mano bendata come una cosa mia e non mia, né saprei dire se m'inspiri tenerezza e pietà o piuttosto ripugnanza (CHIESA, 1973, p. 113)

A reação desesperada e instintiva do cachorro quando preso é de morder seu dono (CHIESA, 1973, p. 113)

Aggomitolo la corda, me la nascondo in tasca e gli torno incontro con tutte e due le braccia protese... Si lascia finalmente raggiungere, carezzare, prendere per il collare. Ma, appena s'accorge della corda che traggo di tasca, diventa bestia feroce. Si libera dalla mia stretta... Arrivo a tempo ad afferrargli una zampa. Lui si rivolta e mi morde a sangue la mano.

Enquanto a mulher e filha procuram desinfetar a ferida, tomados de surpresa, Manlio faz o que julga ser o necessário, correto, diante da situação. Isto é, liquida o animalzinho com um tiro certeiro, o executa. Quando se dá conta do ocorrido o pai exibe uma ponta de orgulho mórbido com a firmeza de Manlio (CHIESA, 1973, p. 113)

"Ed ecco i miei. Spavento, grida, acqua, disingettanti, bende... Poi quel colpa d'arma da fuoco in fondo al frutteto. Un sol colpo: non sapevo che Manlio sapesse tirare con tanta sicurrezza." 
Um extrato do realista Martini (2005, p. 94), escrito cerca de trinta anos tarde:

- Andiamo, Gori, non ci pensare più.

E m'insegnava a vedere il mio come uno dei tanti casi del nostro paese; non sarei andato via se per noi emigrare non fosse stata una tradizione.

- A me è proprio toccata la sorte del soldate che ci lascia la pelle l'ultimo giorno di guerra per un colpo sparato a caso.

Partire, tornare, non essere più né di qua né di là. Ricordavo i salmoni che avevo visti risalire la corrente del Salmoncreek; si dibattevano ostinati nell'acqua per tornare ai luoghi d'origine; siccome l'acqua era bassa i loro dorsi affioravano, e noi li infilavamo con le forche.

Após o fim de CAM é que percebem que agiram impulsionados pelos seus próprios medos. O irreversível já havia sido feito. "SABATO. - È arrivato il responso dell'Istituto antirabbico: niente idrofobia”. (CHIESA, 1973, p. 113)

\subsection{Hoje fiz um inimigo}

Um dos momentos marcantes pela construção do cenário das personagens inusitadas e modernidade temática em Io e i miei é o capítulo "Hoje fiz um inimigo". A princípio, ao ouvir tal notícia, que é novamente, o inverso do que seria o normal, sua família inteira estranha. Afinal, ele, um recatado e polido senhor (de certa forma uma representação do próprio Chiesa como pessoa) ter feito inimizade? O normal seria fazer amizades...

Ele procura se explicar... (CHIESA, 1973, p. 92)

Io - Sí, cari, oggi mi son fatto un nemico. È uno di quei nemici che non perdonano. Quell'uomo non mi aspetterà, no, dietro un cantone col trombone spianato; non mi manderà un sicario. È un personaggio di bei modi, niente inclinato, che io sappia, al sangue.

Como assim? As indagações se sucedem. Primeiro é a mulher que questiona e depois, os filhos. Um inspetor florestal como ele, possivelmente uma das profissões mais "neutras" possíveis, pois tratava mais com plantas do que humanos, gerar conflito? (CHIESA, 1973, p. 
Se na maioria dos outros momentos da narrativa é ele o pai que comenta, por vezes como que conversando, remoendo-se consigo mesmo, os dramas da família, desta feita são suas desventuras que sobem ao palco principal.

Os filhos, curiosos, possuem suas próprias teorias a respeito do que possa ter acontecido (CHIESA, 1973, p. 94). Manlio, por exemplo, conjectura que ele tenha sido forçado, por via das circunstâncias a depor em juízo contra alguém, portanto, fazendo-lhe a inimizade. Contudo, prontamente o pai lhe assegura: trata-se de outra coisa. Com isto, intervem a filha, ela também com um palpite criativo do que poderia ter ocorrido.

Segundo ela, trataria-se de uma das famosas gafes de seu pai, que em seus olhos é nítidamente imperfeito. Ela conta uma história rocambolesca, cheia de fantasia, onde ele teria encontrado a poetisa mais famosa da região na feira do livro. Contudo, de acordo com ela, seu pai tinha apenas noções básicas de poesia. Conhecia o Leopardi e o Aristo, aquele trivial 'básico' que todos teoricamente aprendem no colégio (nítidamente aqui outra referência à italianiedade de sua terra). Por isto, devido à sua falta de refino literário, segundo ela, tinha dificuldades em entender a poesia da "tal da tal". No fundo, ele a julga ridícula e comenta isto com um outro senhor ao lado, sem saber que ele era na realidade o marido da tal. 


\subsection{Coisas que acontecem}

Ci erano capitate tre o quattro disgrazie: non mortali, disavventure piuttosto che sventure, ma l'una dopo l'altra, l'una a cavallo dell'altra, da fare massa; e la mia povera moglie si sentiva oppressa e avvilita come sotto il peso d'un unico gravissimo male. E io m'adoperavo a distinguere cosa da cosa, ad insegnarle che le disgrazie, anche se pare che facciano grappolo, sono acini disgiunti, non più bruschi di quanto ciascuno è brusco (CHIESA, 1973, p. 100)

Neste ponto, o leitor de Chiesa, que provavelmente terá lido Tempo de marzo primeiro, mesmo que na escola, reconhece imediatamente a semelhança. Desta vez é o pai, uma espécie de Nino crescido, mais maduro e feito sábio pelas desaventuras de seus dois casamentos que pronuncia a palavra. Contudo, a maneira de encarar a situação é distinta, se observarmos mais atentamente.

O senhor Andrea e a senhora Faustina, pais do garoto, procuravam, por vezes desesperadamente maneiras de escapar de certas situações. Enquanto em Tempo di marzo, Nino foi enviado a casa de parentes, em um nítido gesto racional, de modo a economizar na alimentação e proporcionar espaço na casa, em Io e i miei, a filosofia do pai é distinta. Ele aceita os infortúnios resignadamente. Se diz feliz, mesmo com as simultâneas tragédias, pois, em sua mente já moldada em um certo modo de pensar, feita obliqua pelas sucessivas tristezas, pensa ao contrário quando lhe convém. A idéia de que 'digeriria' estes acontecimentos um a um, lhe reconforta (CHIESA, 1973, p. 100).

Tutte disgrazie, certo, ma da pigliare una ad una, per quel che valgono, non da cementare insieme per comporre il macigno che si schiaccia. Digeriri i cattivi bocconi ad uno ad uno... - Eh, già: tu sei un'anima felice.

Queixa-se com a esposa de seu funcionário, que ele descreve sem usar o nome, apenas classificando-o como "meu subalterno". Segundo ele, é um desequilibrado, pois empregaria seu tempo e energia metade em armazenar informações úteis e uma outra parte em acumular frivolidades. No fundo, o considera um 'imbecil' pois apesar de ter um certo intelecto, o desperdiça com sua “insubordinação” (CHIESA, 1973, p. 100 e 101). 
Un altro giorno, rivedo le bucce ad un mio subalterno: uomo intelligente, laborioso, bravo, onestà specchiata, mani che, a immergerle nei tesori di Creso, non ci si appiccica il valore d'un quattrino; ma cranio asimmetrico, testa capace d'un'infinità di cose utili, inutili; ma ordine, orario, disciplina, neppure la minima idea.

Referente a seu chefe, que ele descreve também secamente como seu "superior hierárquico", prossegue sua cantilena. Toma como um insulto pessoal a opinião expressada por ele, que considerar seu "subalterno" bom empregado. Quando esboça alguma reação ou sentimento de questionamento, é de imediato 'podado' (ao usarmos uma metáfora botânica).

Possui uma crença reprimida, que o atormenta, de que seu chefe é um chucro, ignorante, inculto. Segundo ele, via de regra, inicia com uma negativa todas suas sentenças. E quando exasperado, indaga novamente sobre algo, recebe a resposta de que lá no ambiente de trabalho onde se encontram ninguém era filósofo nem poeta. 


\section{CONCLUSÃO}

Nas veias literárias de Francesco Chiesa existe um grande apego e identificação com sua terra. O vínculo com o piccolo paese, o comune ou em maior escala a província (cantão, no caso do contexto helvético) de onde se vem e se tem as raízes familiares é forte e duradouro.

Chiesa foi uma espécie de pilar dos escritores da Suíça italiana. Alguns críticos, ao verem sua produção com os olhos de hoje, podem considerar sua escrita "classiquejante". Mas o que sabemos do bom artesanato e do trabalho árduo e continuo de polimento de pedras e vocábulos é que eles duram. Foi o primeiro a desbravar o árduo mercado editorial italiano, a colocar o nome de sua região nos manuais de língua e literatura, e por esse feito será lembrado, juntamente com seu empenho em manter vivos os laços culturais e históricos com a península.

Misturada à sua maestria lírica, o primeiro grande poeta de Ticino adicionava boas esculpidas de árdua elaboração e correção às suas obras. Seções inteiras de livros foram refeitas, sonetos reescritos em edições posteriores. Para atingir aquele ideal de língua mais próximo possível de Dante e Manzoni. Tal afinco e dedicação refletem-se em sua carreira de trinta anos como professor de italiano e posteriormente de história da arte. Suas atividades de jornalista, assim como de pioneiro diretor da biblioteca cantonal também merecem ser devidamente recordadas.

Mesmo que os temores de Chiesa tivessem se concretizado e seu cantão sofrido um processo de aculturação lingüística (como ocorre hoje em certas áreas da Engadina), seus livros ainda estariam aí, como registro "arqueológico" dessa realidade de antigamente, pois mesmo em tradução foram grande sucesso nas regiões de língua alemã de seu país. 
Quando vemos essas obras acabadas, percebemos o talento artesanal e empenho em trabalhar as palavras do "artefice". Franceso Chiesa quase nos faz crer que todos escrevemos italiano assim, na forma ideal, que conforme observamos, na visão chiesiana era a “clássica, a ideal e universal, epicentro da civilização italiana". Ou seja o florentino idealizado e padrão de um elegante vocábulo como chicchera $^{14}$.

O gênio Montale (1997, p. 274 e 275) afirma em sua obra de antologia poética (em trecho de entrevista que realizou com o poeta em Lugano em 1952, inicialmente publicada no Corriere della Sera) que ao conversar com Chiesa tinha a impressão de falar como um toscano, em vez de um lombardo. Sua inspiração vem do Arno, concluiu.

Em Io e i miei, o poeta do Ticino é muito mais que isso, superou seus próprios limites de escritor de temática regional e italiano padronizado, trazendo a si as preocupações de uma modernidade tocada pelas incertezas. Antecipou, assim, futuros desenvolvimentos de uma então incipiente mas hoje estabelecida literatura. Helvética na precisão dos apontamentos, européia de vocação e italiana de coração.

\footnotetext{
${ }^{14}$ Em Io e i miei (páginas 15 e 16), por exemplo, Chiesa utiliza esta palavra "manzoniana".
} 


\section{Apêndice A - SOBRE A SUÍÇA}

\section{Primeiros cantões independentes}

Emilio Papa, em sua História da Suiça, observa que o alicerce fundamental da confederação, seu núcleo vital e impulsionador no campo das idéias, sua base histórica de referência, é a liga dos três cantões ditos iniciais, os Waldstätten (“terras dos bosques”).

Agrupadas sob a proteção de modestos senhores feudais, as três comunidades de camponeses libertos e pastores, aproveitando-se bem das disputas entre o papado e o Império, souberam conseguir para si importantes privilégios, de modo a estender e reforçar sua autonomia e influência sobre a área geográfica que hoje conhecemos como a Suíça central (próxima à atual Lucerna) (Papa, 2004, p. 31).

Esse terceto de cantões era composto pelos três vales florestais, chamados Schwyz, Uri e Unterwalden. Juraram mútua assistência, na forma "de ajuda, conselho e favores". Afirmaram seu direito a determinar a maneira de serem governados, em nome de todos os habitantes dos três vales, inclusive dos "não livres". Estes (servos), no caso, eram sujeitos primeiramente à aliança confederal sancionada pelo pacto e, em segundo plano, aos respectivos senhores que continuavam a servir.

O historiador então observa que, dessa maneira, a aliança deles supera as fronteiras do direito feudal e afirma, em forma embrionária, a natureza do Estado moderno (Papa, 2004, p. 25-26).

Ao norte, foi formada uma liga de cidades e vilas urbanizadas, quase todas ligadas ao Império, em torno do lago de Constança. Seus integrantes principais foram Constança, Schaffhausen, São Galo e Zurique (Papa, 2004, p. 31). 
Esta última, assediada na primavera de 1292 (ano seguinte à assinatura do pacto entre os três cantões dos bosques) por Alberto da Áustria, filho do imperador Rodolfo, finalmente obteve sua vitória em Winterthur, no dia 12 de abril daquele ano (Papa, 2004, p. 31-32).

As querelas internas do Império aumentaram após o assassinato de Alberto, em 1308, pelo seu sobrinho João. Isso fez com que o conde de Luxemburgo fosse eleito seu sucessor. Os três cantões se aliaram ao Império na luta contra os Habsburgos. Uma década antes, em 1297, o imperador havia ratificado as importantes "franquias imperiais" já concedidas a Uri e Schwyz, de grande valor estratégico e econômico.

Alguns anos mais tarde, em 1314, eclode uma verdadeira guerra pelo trono entre Luís, o Bávaro, e o duque Frederico de Habsburgo. Ao alinhar-se a Luís, os cantões provocam a ira dos Habsburgos, que encaram isso como uma reles provocação de súditos infiéis e, por conseguinte, aprontam uma expedição com o intuito de "puni-los" exemplarmente pela desobediência (Papa, 2004, p. 33).

Todavia, nos combates de Brünig (na fronteira com Unterwalden) e posteriormente em Morgarten (na fronteira com o cantão de Svitta, que deu origem ao estandarte e nome do país), os três cantões emergiram vencedores, contribuindo assim para selar definitivamente seu destino comum (Papa, 2004, p. 33).

Apontam os historiadores que a origem da confederação está nestas alianças de cidades e regiões, situadas geograficamente no planalto central, em torno ao Lago de Lucerna, conhecido como "Lago dos Quatro Cantões". Conforme se auto-declaravam livres do jugo do império e dos senhores feudais locais, estes povos de origem germânica mas com dialeto e tradições próprias, portanto grande apego à terra e sensação de pertença e unidade, se motivavam a extender sua presença, o que chamava a atenção de seus antigos mestres, que pretendiam retaliar. 
Este forte sentimento republicano é uma característica destas regiões, que contudo, ainda tiveram que se provar novamente, de modo a assegurar sua independência. Observamos que as batalhas ocorridas durante o período de emancipação suíça foram ferocíssimas, mesmo tomando-se em conta os padrões medievais, com combates corpo a corpo e mutilações de soldados, conforme retratado ${ }^{15}$ abaixo:

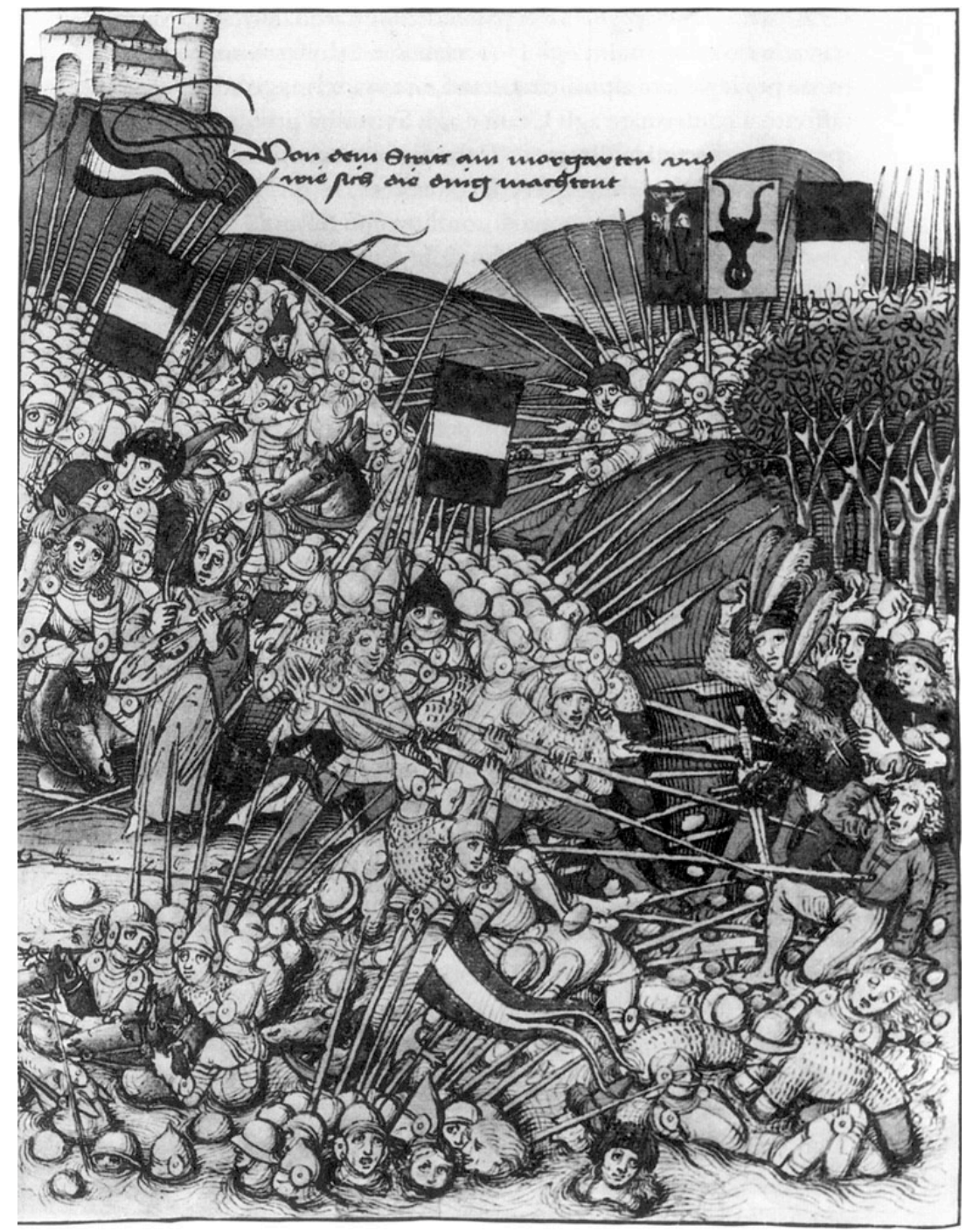

Figura 4. Representação da batalha de Morgarten

(em FAHRNI, 1994, p. 23)

\footnotetext{
${ }^{15}$ Os soldados da infantaria suíça utilizavam como arma principal uma vara pontiaguda e afiada na extremidade. Em formação, tornavam-se uma oposição formidável contra até a mais treinada das cavalarias. Realizada por um combatente com evidentes dons artísticos, a figura demonstra a tradição de arte gótica de sua cultura.
} 
Em Morgarten, na manhã de 15 de Novembro de 1315, de um lado estavam as tropas Habsbúrgicas, superiores em número e que contavam com uma experiente cavalaria, sob o comando do duque Leopoldo de Habsburgo, filho do imperador Alberto. Na defesa, estava o exército formado pelos montanheses dos Waldstatten. $\mathrm{O}$ resultado foi a primeira grande vitória helvética contra o império. Nascera então a fama de imbatível da infantaria suíça que persistiria até a invasão napoleônica quase quinhenhos anos mais tarde.

Conforme observam (KOENIGSBERGER; MOSSE; BOWLER, 1999, p. 110) estas cidades suíças, com o tempo adquiririam um prestígio militar desproporcional a sua pequena extensão geográfica. Devido à sua treinada infantaria, conseguiram estender seu domínio às regiões rurais circunstantes, consideradas essenciais à sobrevivência e desenvolvimento dos centros urbanos e freqüente motivo de guerras entre as cidades-estado, sobretudo italianas e alemãs.

Soltanto le città svizzere, sebbene non fossero né ricche né popolose come le grandi
città italiane e tedesche, riuscirono a estendere il proprio dominio su un ampio
contado. Inoltre, la loro confederazione con le libere comunità contadine dei cantoni
alpini di Schwyz, Uri, Unterwalden e Glarona, famosi per la loro addestrata fanteria,
offriva alla Confederazione elvetica un potenziale militare al di là di ogni
proporzione rispetto all'importanza economica delle città. Os exércitos helvéticos eram compostos por verdadeiras legiões de camponeses pobres, que por dinheiro, glória ou ambos, desciam dos alpes com suas lanças de cinco, seis metros de comprimento, cujas pontas dilaceravam homens, cavalos e tudo o que se movesse em sua frente. Animados por suas continuadas vitórias, expandiram ao sul. Atravessaram as montanhas e adentraram na planície lombarda, atacando os postos avançados do Ducado de Milão, situados ao norte (KOENIGSBERGER; MOSSE; BOWLER, 1999, p. 110).

I suoi reggimenti di picchieri ben addestrati e crudeli, che provenivano dai villaggi sovrappopolati della montagna, avevano sconfitto Carlo 'il Temerario nel 1476 e nel 1477, e avevano respinto Massimiliano I nel 1499. Francesco I li sconfisse a Marignano, nel 1515, arrestando l'espansione elvetica nella pianura lombarda; ma, fino alla Rivoluzione francese, nessuna delle grandi potenze osò attaccare di nuovo direttamente la Confederazione. 


\section{Curia Rhætorum}

Nas montanhas, foi fundada a Curia Rhætorum, como era conhecida pelos romanos. Foi centro militar estratégico em meio a grandes florestas. Na época medieval, Curia manteve sua importância por abrigar uma poderosa sede episcopal. Seu representante tinha domínio sobre toda a região circunstante, mas que no quotidiano era governada pelas ditas “corporações".

Em janeiro de 1367, Curia e os municípios vizinhos associaram-se a seus homólogos da Engadina, na chamada Federação da Casa de Deus. ${ }^{16}$ Essa associação é conhecida como "Lega Caddea" na documentação em italiano. No decorrer do século seguinte, essa liga se fortaleceria com a adesão de importantes componentes.

Incentivados por uma necessidade comum de defesa, o pacto de assistência militar seria ampliado até os Grisões, com a formação de várias ligas menores nessas pequenas comunidades alpinas, em áreas da diocese de Disentis.

Em todo caso, essas incipientes alianças ficaram conhecidas como Liga Cinza (Graubünden), viriam a dar o nome à região que persiste até os dias atuais (i.e., Cantão de Graubünden). Os Grigioni, como são conhecidos em italiano, foram formados em 1395 e cinco anos mais tarde, em 1400, realizaram uma aliança com Glarus, que reforçou ainda mais o pacto. São aproximadamente 150 comunas.

\footnotetext{
${ }^{16}$ Gotteshausbund.
} 


\section{Cantão dos Grisões}

O cantão plurilíngüe dos Grisões (Graubünden em alemão, Grissuns em romanche, Grigioni em italiano) é hoje o maior da Suíça em extensão territorial e possivelmente o mais montanhoso e de difícil acesso. Em suas fronteiras políticas coexistem três idiomas, agrupados por regiões. Antiga sede do falar romanche em tempos medievais, Curia passou por um processo de germanização séculos atrás, e hoje, apesar de essas comunidades haverem logrado em 1979 o reconhecimento do romanche como idioma oficial, este (em suas variantes ladina e friuliana) resiste apenas nos municípios rurais.

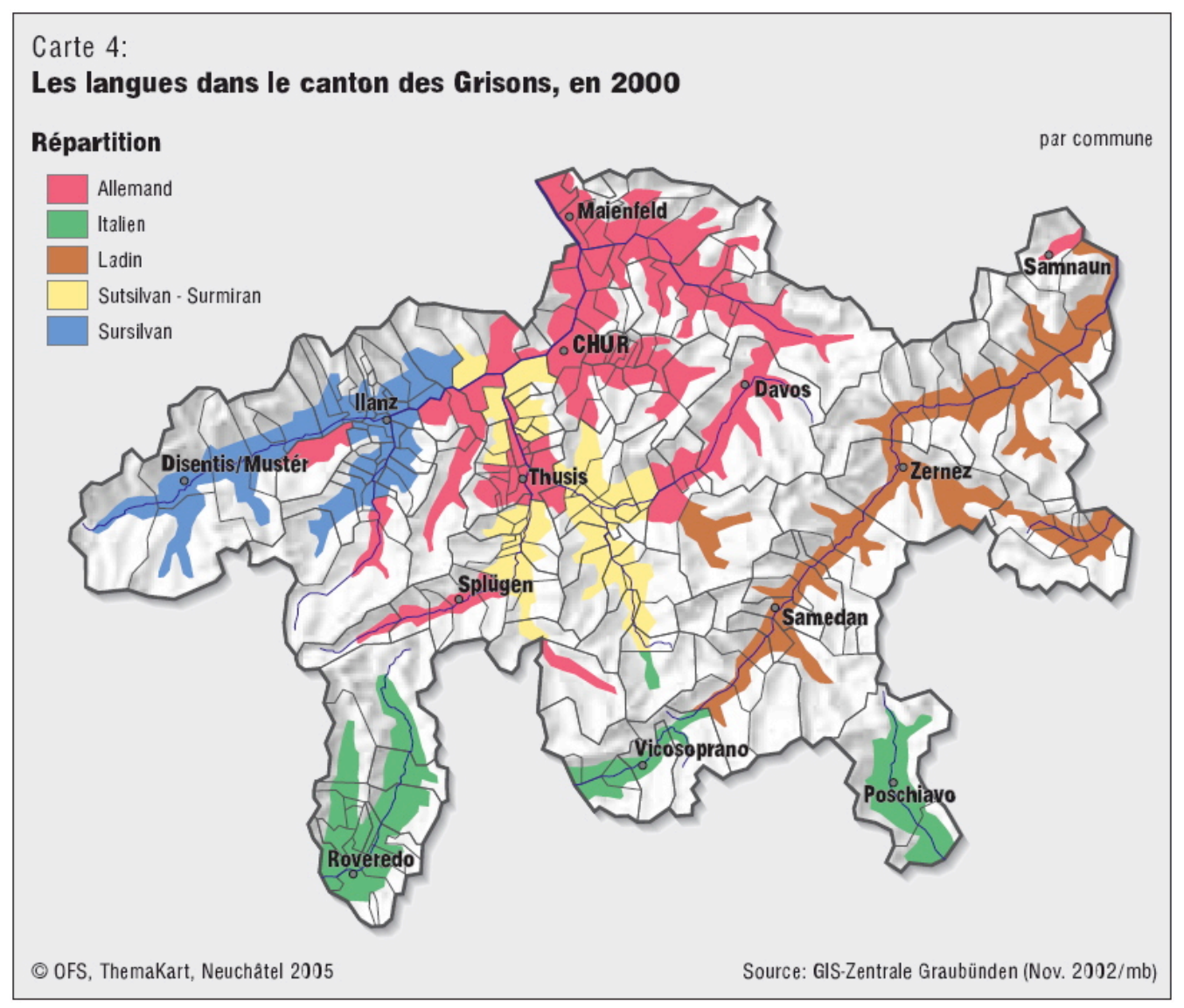

Figura 5 - Mapa lingüístico dos Grisões (por município)

Fonte: Escritório Federal de Estatística, com base em dados cantonais de 2002. 
A região abriga a quarta língua nacional e possui uma tradição literária, que lhe é própria, ligada aos acontecimentos históricos (conforme descritos na seção anterior) e políticos da "pequena pátria" que é essa região. É um idioma só falado entre as fronteiras suíças, portanto intimamente ligado ao território, como aponta o crítico literário e historiador Guido Calgari (1968, p. 283):

La Svizzera retoromancia, poi, per il fatto stesso di usare una lingua che è dichiarata «nazionale» soltanto in Svizzera, è la più qualificata di tutte a parlare di letteratura originale; la sua poesia, almeno quella epica ma in certa misura anche lirica, e la sua novellistica, s'identificano con la vicenda politica e spirituale della piccola patria "tra le montagne, con la storia della Rezia e delle Leghe grigionesi, prefigurazione della libertà elvetica e della democrazia alpina, come s'è visto. 


\section{Organização administrativa atual}

A Confederação Suíça (Confœderatio Helvetica, nome oficial, em latim) é uma federação desde 1848. Administrativamente, compõe-se de 26 cantões de tamanhos variados, que se formaram ao longo da história e contam com ampla autonomia quando comparados internacionalmente. Três desses cantões subdividem-se em semi-cantões.

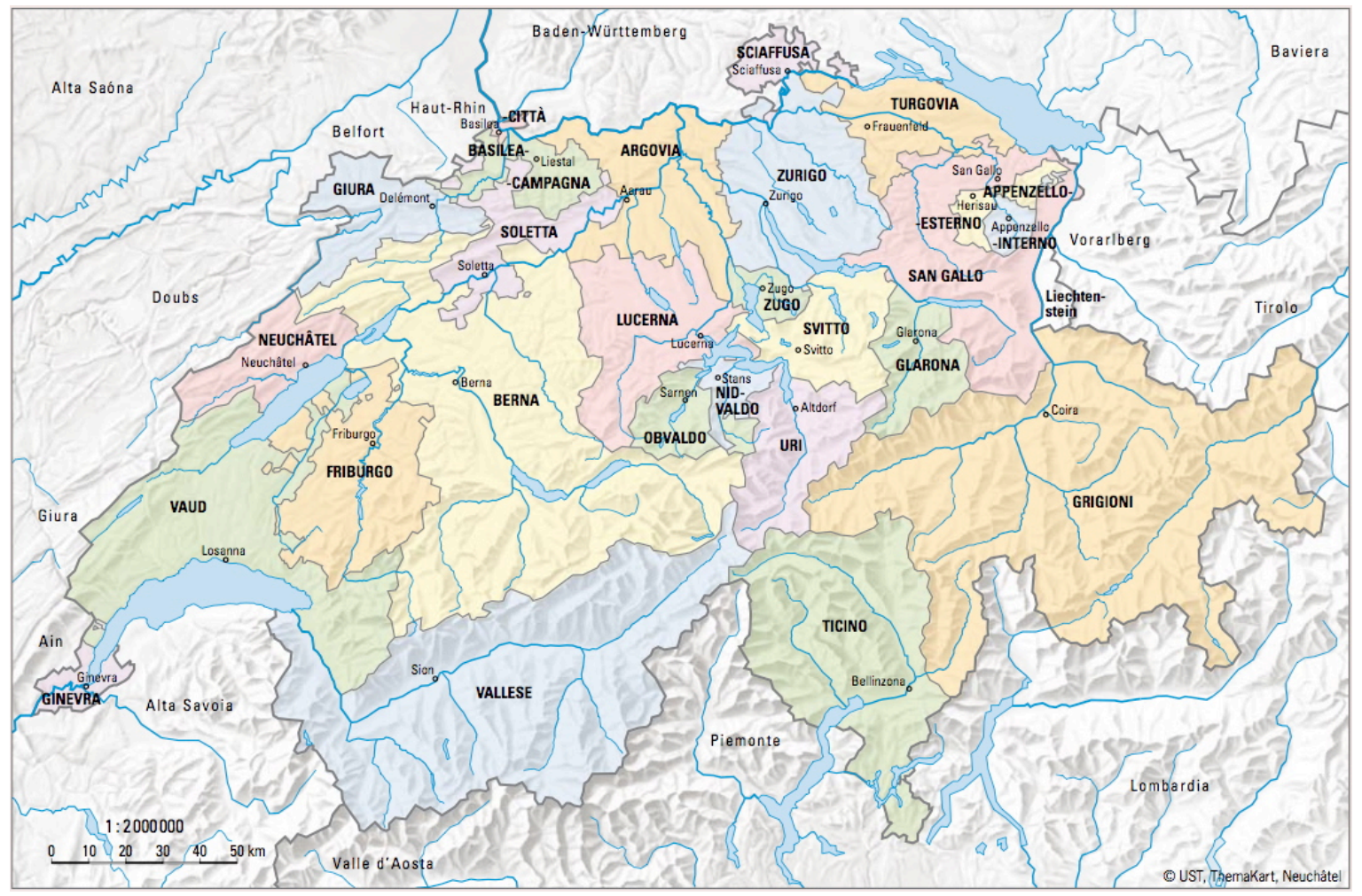

Figura 6 - Mapa da estrutura político-administrativa suíça

Fonte: Ufficio Federale di Statistica, Neuchâtel. 
O Parlamento helvético é bicameral, com o Conselho Nacional (que representa o povo, com 200 assentos) e o Conselho dos Estados (com 46 lugares). O Executivo, também denominado Conselho Federal, é composto por sete membros eleitos por mandatos de quatro anos. O sistema político suíço se distingue dos do resto do mundo por apresentar direitos de iniciativa e referendos, dos quais o cidadão pode participar (i.e., votar), em inúmeras questões, várias vezes ao ano (DATI STATISTICHI DELLA SVIZZERA, 2008, p. 486)

La Confederazione Svizzera (o Confœederatio Helvetica) è uno Stato federale dal 1848. Si suddivide in 26 Cantoni di grandezza molto diversa, formatisi nel corso della storia, che godono di un'ampia autonomia nel confronto internazionale. Dal 1959, i quattro partiti più forti (Partito liberale radicale, Partito socialista, Partito popolare democratico e Unione democratica di centro) formano congiuntamente il governo federale (Consiglio federale), composto da sette membri, eletti dal Parlamento per un periodo di quattro anni. Il Parlamento è formato da due Camere: il Consiglio nazionale (che rappresenta il popolo, 200 seggi) e il Consiglio degli Stati (che rappresenta i Cantoni, 46 seggi). Il sistema politico della Svizzera si contraddistingue inoltre per i diritti popolari molto estesi (diritto di iniziativa e di referendum) e votazioni popolari su questioni specifiche più volte all'anno.

\section{Território}

A Suíça possui uma superfície de 41 mil quilômetros quadrados, semelhante à área do estado do Rio de Janeiro. Com cerca de 7 milhões de habitantes, é comparável em população à capital fluminense. Os Alpes constituem uma fronteira geográfica entre o norte e o sul desse país que tem quatro idiomas oficiais: o alemão, o francês, o italiano e o romanche (DATI STATISTICHI DELLA SVIZZERA, 2008).

A Suíça se caracteriza por sua grande diversidade. O país é dividido em três principais áreas geográficas: o Jura, o Altiplano e os Alpes. Existem diferenças climáticas entre essas regiões, onde, de acordo com as estações do ano, o tempo pode ser semelhante ao da Sibéria ou ensolarado como o de um país mediterrâneo. Embora sofra com a falta de disponibilidade de espaços construídos (devido à sua alta densidade populacional), as leis de preservação do 
patrimônio histórico (já observamos que, no caso do cantão de Ticino, Francesco Chiesa foi um de seus maiores proponentes) estimulam que o caráter arquitetônico típico de suas cidades e vilarejos seja mantido (INFORMAZIONI SULLA GEOGRAFIA SVIZZERA, 2008).

La geografia della Svizzera si distingue per la grande diversità. Il paese si suddivide in tre principali aree geografiche: il Giura, l'Altopiano e le Alpi. Questa varietà geografica si ripercuote anche sul clima delle regioni, che, a seconda della stagione e del periodo dell'anno, assimila la Svizzera alla Siberia o ai paesi mediterranei. Anche le città principali conservano un loro carattere ben distinto. La disponibilità di terreni edificabili è inferiore alla domanda, ma piani regolatori oculati mirano a mantenere l'aspetto delle città e dei villaggi.

Outra característica geográfica importante é a presença de grande quantidade de água doce. Em território helvético encontram-se as nascentes de rios de extensão continental, tais como o Reno, o Ródano, o Inn e, logo após a fronteira da Alemanha, o Danúbio, que desembocam em vários mares diferentes (do Norte, Mediterrâneo e Negro). A Suíça abriga em suas fronteiras mais de 1.500 lagos, sendo que os dois principais, o de Constança e o de Léman, definem ao nordeste os limites com a Alemanha e a sudoeste os confins com a França (RISORSE IDRICHE, 2008).

Con il 6\% delle riserve d'acqua dolce di tutta l'Europa la Svizzera è considerata, non a torto, il paese delle acque. Sul suo territorio si trovano le sorgenti di Reno, Rodano e Inn, tre dei principali fiumi continentali e che sfociano poi in tre mari diversi: il Mare del Nord, il Mar Mediterraneo e il Mar Nero. Qualche chilometro a valle della città di Sciaffusa si trovano le Cascate del Reno che, con un'ampiezza di $150 \mathrm{~m}$ e un'altezza di $25 \mathrm{~m}$, sono le più estese d'Europa. La Svizzera vanta inoltre più di 1'500 laghi; i due principali, il Lago di Costanza e il Lago Lemano, si trovano alle estremità opposte del paese e le loro acque segnano rispettivamente parte del confine con Germania e Austria e con la Francia. Il Lago Lemano, detto anche Lago di Ginevra, è il maggiore bacino di acqua dolce dell'Europa occidentale. 
As montanhas do país são fator de reconhecimento internacional e funcionam como espécie de componente auto-biográfico na literatura autóctone, em obras de escritores como Gottfried Keller (O Henrique verde $\left.{ }^{17}\right)$ e Giovanni Orelli (L'anno della valanga).

Os Alpes suíços têm uma largura média de 200 quilômetros e uma altitude média de 1.700 metros. A imagem de cartão-postal dos Alpes contribuiu de maneira preponderante para a identidade nacional do país, apesar de a atividade econômica estar concentrada sobretudo no Altiplano. Na altitude de 2.500 metros inicia-se a faixa das neves eternas (LE ALPI, 2008).

\section{Descentralização e autonomia cantonal}

Devido ao seu desenvolvimento histórico na confluência de diversos povos e nações da Europa medieval, a Suíça desenvolveu uma espécie de equilíbrio lingüístico, em teoria. A língua falada no quotidiano pelos cidadãos pode variar, dependendo do cantão (unidade administrativa básica suíça, que seria equivalente a um estado brasileiro, guardadas as devidas proporções geográficas continentais do Brasil) onde a pessoa estiver no momento.

Ou seja, é possível que um suíço fale francês em sua cidade natal e italiano ou alemão no trabalho, ao tomar o trem e atravessar alguma montanha. Existem até casos de cidades que são verdadeiramente bilingües, onde em certos bairros se fala alemão e outros francês, por exemplo. Mesmo os nomes de ruas, placas e sinalizações mudam, passando-se se a chamar Strasse $^{18}$ ou Rue, respectivamente, dependendo do lado que se estiver da invisível, mas sempre presente, fronteira lingüística.

\footnotetext{
17 Título original: "Der grüne Heinrich". Considerado o maior escritor suíço do XIX (cfr. CAMARTIN, p. 29).

${ }^{18}$ Tradicional grafia Suíço-alemã de Straße (rua).
} 
Os cantões funcionam como se fossem a "primeira pátria" dos cidadãos, pois existe um grande grau de regionalismo e sentimento de pertença a cada um deles, mais acentuado até do que a noção que os brasileiros têm do que significa ser acreano, rio-grandense, paulista ou fluminense. Seus limites administrativos, por sua vez, são bem mais visíveis que os lingüísticos e fazem-se sentir diretamente na vida das pessoas, pois cada qual tem suas leis e regulamentações próprias. Somente assuntos de âmbito estritamente nacional (entendidos na ótica suíça) e de interesse comum a vários cantões, tais como ferrovias, construção de túneis, defesa do território e assim por diante, são de competência do governo federal sediado em Berna.

Com efeito, a autonomia local dos cantões é bastante ampla e remonta aos tempos medievais. É portanto, muito maior de qualquer estado brasileiro. Cada cantão pode, por exemplo, definir qual língua ou línguas serão empregadas na administração pública e no ensino.

Ilustramos, portanto, que cada uma destas unidades administrativas historicamente possui poderes e atribuições bem amplas. Em certos casos, podem até estabelecer políticas lingüísticas e controles fronteiriços próprios com os países vizinhos, no intuito de teoricamente "salvaguardar" a especificidade de cada cantão. 


\section{Apêndice B - SUÍÇA DE LÍNGUA ITALIANA}

\section{Encruzilhada estratégica}

Afirma Bianconi $(1989$, p. 25) que as terras cisalpinas que viriam a constituir o cantão de Ticino pertencem, do ponto de vista geográfico e ambiental, às regiões mediterrâneas préalpinas e alpinas estudadas e descritas por Fernand Braudel em O Mediterrâneo e o mundo mediterrâneo na época de Filipe II, as quais compartilham entre si as condições de vida, cultura e tradições.

Do ponto de vista político e administrativo, foram províncias periféricas do Ducado de Milão. Contudo, sua importância econômica é realçada pela localização na fronteira com os Alpes e o mundo germânico. Passa pela região um dos eixos comerciais de maior trânsito da Europa medieval (fenômeno esse que persiste, de certa forma, até nossos dias): a estrada que passa pelo Túnel de São Gotardo (BIANCONI, 1989, p.25).

Cientes de sua posição estratégica, os habitantes do outro lado da montanha, isto é , os três cantões germanófonos fundadores da Suíça realizaram diversas incursões e tentativas de conquista, dentro de sua política expansionista. Os urinos (naturais do cantão de Uri) em especial, se encontraram em encarniçadas batalhas com os milaneses: com o exército viscônteo em Arbedo (1422) e, posteriormente, com o sforzesco em Giornico (1478). Primeiro o vale da Levantina, depois o de Blênio, a Riviera e Bellinzona passaram, até 1500, para o domínio helveta (BIANCONI, 1989, p .25). 


\section{Língua de Chancelaria}

No início do XVI, época de forte plurilinguismo, coexistem quatro sistemas lingüísticos nas comunicações cultas (ex: dos funcionários públicos e notários): o latim, o italiano chancelereiro, o italiano regional com fortes traços dialetais e a variedade toscana. Afirma Bianconi que a presença deste plurilinguismo se dá em diversos níveis. Ou seja, em uma mesma comunicação podem co-habitar elementos latinos e toscanos, dialetais e chancelerereiros, etc. (BIANCONI, 1989, p.32)

Ilustramos abaixo alguns dos vocábulos destas tradições:

Tabela 2 - Vocábulos presentes em textos de Brissago

\begin{tabular}{|l|l|l|}
\hline Língua de chancelaria & Italiano regional & Italiano toscano \\
\hline fratelo & fredel, fradil & fratello \\
\hline canepario & canavé & camerlingo \\
\hline dinarii & dané & denari \\
\hline benedicto & binison & benedetto \\
\hline genaro & gené, zené & genaio \\
\hline prandio & disnà & colazione \\
\hline oleo & ori & olio \\
\hline Petro & Pedro, Pedero & Piero \\
\hline
\end{tabular}

Fonte: (BIANCONI, 1989, p. 33) 
Che ciaschaduno sia tenuto lasar le strade larghe per braccia sei.

Item hano statuito et ordinato che ciaschuno de ditto Comune

et homini de Carona et Giona che hano

da fare appreso le strade del predeto Comune

quale uanne tanto per la campagna come altronde per tutto il tereturio

de dito Comune de Carona et Giona siano tenuto et debiano

lasar le preditte strade del Comune larghe de braza sei

in largheza per ogno loco cioè bracia tre de soto et bracia tre de sopra

incominciando a musurare in mezzo della metà della strada

che ciaschuno che ha terre appresa a ditte strade patischa

per la sua parte de tre ditte bracia come di sopra se fa

mencione et questo solo la pena de soldi diece de terzoli

per ciaschaduno et per qualoncha uolta

da esse esplicata come de sopra.

Figura 7 - Ilustração dos estatutos da cidade de Carona ${ }^{19}$ (1482)

${ }^{19}$ Fonte: BIANCONI, 1989, p. 26 e 27 


\section{Conceito formal de Suíça italiana}

Neste trabalho adotamos a definição oficial de regiões lingüísticas, aplicada pelo governo suíço, que é aquela predominantemente ligada ao território. A partir desta, derivamos o conceito de Suíça italiana.

O Escritório Federal de Estatística, em Neuchâtel, define a região lingüíistica com base na língua majoritária dos respectivos municípios suíços. Em casos raros, pode ocorrer uma divergência entre a definição estatística e o critério político de atribuição a uma determinada região lingüíistica. Por isso, pode-se dar que certas comunidades mudem de região idiomática após a realização de um censo, como conseqüência da evolução de sua população e do número de falantes das diversas linguas. Por exemplo, o recenseamento de 2000 mostrou que a comuna ticinense de Bosco-Gurin $^{20}$ possuía pela primeira vez uma população majoritariamente italófona. Ela foi, portanto, atribuída à região de língua italiana. Cinco comunas romanches passaram à área germanófona em 2000, quer dizer, tantas quantas em $1990 . .^{21}$

Em outras palavras, a Suíça italiana é definida como o conjunto de territórios helvéticos onde o idioma de Dante é a lingua da maioria da população. Em termos práticos administrativos, isso significa, desde 2000, que ela é composta do cantão de Ticino em sua integridade e partes do cantão de Graubünden (Grisões, onde há um predomínio do alemão em linhas gerais, com presença histórica do romanche, mas que em certas comunas se fala o italiano).

\footnotetext{
${ }^{20}$ A prefeitura possui um sítio na Internet: $\underline{w w w . b o s c o-g u r i n . c h}$

${ }^{21}$ Por vários séculos esse foi um enclave lingüístico dentro de uma área de fala italiana. Fundado por imigrantes suíços (germanófonos) vindos no século XIII (ainda na época do Ducado de Milão) da região das montanhas a leste de Ticino (no atual cantão Valais, de fala francesa). Seus habitantes comunicam-se em um dialeto próprio e mantiveram suas culturas e tradições.
} 


\section{Cantão de Ticino}

Importante observar que, além de ser a língua materna de boa parte dos habitantes do cantão de Ticino, o italiano constitui o idioma predominante dos negócios e da administração pública, de acordo com dados do censo de 2000.

Tabela 3 - Línguas da vida profissional no cantão de Ticino (por classe de profissão)

\begin{tabular}{|c|c|c|c|c|c|c|c|}
\hline \multirow[t]{2}{*}{ Profissão } & \multicolumn{4}{|c|}{ Línguas Oficias do País } & \multicolumn{2}{|c|}{ Outros Idiomas } & \multirow[t]{2}{*}{ Total } \\
\hline & Alemão & Francês & Italiano & $\mathbf{R M}^{*}$ & Inglês & Diversos & \\
\hline Agropecuária & 18,4 & 7,7 & 98,5 & 0,1 & 2,0 & 3,0 & 2.208 \\
\hline Artes e ofícios & 11,7 & 9,2 & 99,2 & 0,2 & 3,0 & 1,4 & 9.453 \\
\hline Comércio e transportes & 28,0 & 21,4 & 98,4 & 0,2 & 14,6 & 3,0 & 14.806 \\
\hline Construção civil e mineração & 6,8 & 3,8 & 99,4 & 0,1 & 0,9 & 2,2 & 5.753 \\
\hline Gestão, bancos, advocacia & 30,4 & 26,5 & 99,0 & 0,1 & 18,8 & 2,4 & 28.740 \\
\hline Hotéis, restaurantes, serviços & 18,4 & 10,6 & 98,5 & 0,1 & 6,0 & 5,0 & 10.707 \\
\hline Saúde, Ensino, Ciência & 21,8 & 16,7 & 98,3 & 0,1 & 9,7 & 2,3 & 17.200 \\
\hline Técnicas e da informática & 27,8 & 20,8 & 98,6 & 0,2 & 16,6 & 2,2 & 7.242 \\
\hline Outras & 17,8 & 12,9 & 98,3 & 0,2 & 8,2 & 3,2 & 32.790 \\
\hline Total & 22,0 & 16,9 & 98,6 & 0,2 & 11,0 & 2,8 & 128.899 \\
\hline
\end{tabular}

* Romanche

Fonte: Escritório Federal de Estatística, Censo Lingüístico 2000, p. 57.

Segundo este levantamento oficial, múltiplas respostas foram possíveis no quadro acima. Ou seja, ficou evidenciada uma presença de falantes bilingües e trilingües. Os números reforçam o fato que o idioma predominante das profissões no Cantão de Ticino, assim como aquele do lar ${ }^{22}$ é majoritariamente o italiano, atestando assim sua sobrevivência e estabilidade como língua oficial e da vida quotidiana empregada na região.

\footnotetext{
${ }^{22}$ Explicando-se assim eventuais somas superiores a 100\%.
} 


\section{O país das quatro literaturas}

Nomes como Gottfried Keller e Blaise Cendars, por exemplo, surgem como candidatos naturais a carregar a tocha olímpica, por assim dizer, a representar literariamente suas respectivas regiões e seu país no mecanismo sincronizado e bem ordenado de idiomas que é a Suíça. Da parte romanche, mesmo tendo escrito extensivamente em alemão, poderíamos razoavelmente incluir o nome de Iso Camartin.

Completando esta moldura do país alpino com comunidades e tradições geralmente distintas, monolíngües territorialmente, por vezes bilingües, como a capital Berna e Friburgo, temos Francesco Chiesa, o representante da Suíça italiana, região que por boa parte do XIX esteve envolta em tribulações políticas ligadas à recém-conquistada independência dos antigos balliagi italiani (regiões da Lombardia medieval que no início do século XVI haviam passado à jurisdição helveta, conforme observamos na seção 1), mas que despontou nos mapas literários do mundo moderno graças ao poeta Luganês, que lá viveu grande parte de sua vida adulta e produziu a maior parte de seus livros. 


\section{BIBLIOGRAFIA}

AGLIATI, Mario. Raduno a sera di pagine sparse, vols. I e II. Bellinzona: Grassi-Istituto Editoriale Ticinese, 1976.

ASOR ROSA, Alberto. Novecento primo, secondo e terzo. Milano: RCS Libri, 2004.

BIAGINI, Enza; BRETONI, Augusta; ORVIETO, Paulo. Teorie critiche del novecento (con antologia di testi). Roma: Carocci, 2001.

BIANCONI, Sandro. Lingue di frontiera: una storia della Svizzera italiana dal medioevo al duemila. Bellinzona: Casagrande, 2005.

BONALUMI, G.; MARTINIONI, R.; MENGALDO, P. Cento anni di poesia nella Svizzera italiana. Locarno: Dadò, 1997.

CALGARI, Guido. Le 4 letterature della Svizzera. Nuova edizione aggiornata. Firenze: Sansoni, 1968.

CAMARTIN, Iso et al. The four literatures of Switzerland. St. Gall: Pro Helvetia, 1996.

CHIESA, Francesco. Calliope: la cattedrale, la regia, la cità. 3. ed. Roma: Formigini, 1921. ("Poeti Italiani del XX Secolo").

CHIESA, Francesco. Dante Alighieri e Alessandro Manzoni: discorsi commemorativi. Bellinzona: Grassi, 1924.

CHIESA, Francesco. Io e i miei. Lugano: Cantonetto, 1973.

CHIESA, Francesco. Monumenti storici e opere d'arte esistenti nel Cantone Ticino. Lugano: Grassi \& Co, 1928.

CHIESA, Francesco. Racconti puerili. Milano: Mondadori, 1944.

CHIESA, Francesco. Sonetti di San Silvestro. Milano: All'insegna del pesce d'oro, 1971.

CHIESA, Francesco. Tempo di marzo. Locarno: Cantonetto, 1984. 
DATI STATISTICHI DELLA SVIZZERA. Neuchâtel: Ufficio Federale di Statistica, 2008. Publicação do órgão oficial estatístico da Confederação Suíça. Disponível em: <http:// www.bfs.admin.ch/bfs/portal/it/index/dienstleistungen/publikationen_statistik/ statistische_jahrbuecher/stat_jahrbuch_der.Document.76169.pdf $>$. Acesso em: 1 mar. 2008.

DE MEIJER, Pieter; TARTARO, Achille; ROSA, Alberto Asor. La narrativa italiana dalle origini ai giorni nostri. Torino: Einaudi, 1997.

DEIDIER, Roberto. La poesia: lettura e compreensione. Roma: Armando, 1998.

INFORMAZIONI SULLA GEOGRAFIA SVIZZERA. Berna: Presenza Svizzera, 2007. Publicação oficial da Confederação Suíça. Disponível em: <http://www.swissworld.org/it/ geografia/>. Acesso em: 17 fev. 2008.

FAHRNI, Dieter. Storia della Svizzera: sintesi di un piccolo paese dalle origini fino ai nostri giorni. Zürich: Pro Helvetia, 1994.

FUNARI, Pedro P. Grécia e Roma. São Paulo: Contexto, 2006.

GNISCI, Armando; SINOPOLI, Franca. Manuale storico di letteratura comparata. Roma: Meltemi, 1997.

KOENIGSBERGER, H. G.; MOSSE, G.; BOWLER, G. L'Europa del Cinquecento (trad. Europe in the Sixteenth Century). Bari: Laterza, 1999.

LÜDI, Georges; WERLEN, Iwar. Recensement Fédéral de la Population 2000: le paysage linguistique en Suisse. Neuchâtel: Office Fédéral de la Statistique, 2005.

LURATI, Ottavio. Dialetto e italiano regionale nella Svizzera italiana. Lugano: Solari \& Blum, 1976.

MANGAN, Jacqueline. Narrativa della Svizzera Italiana dal '60 a oggi. Tese de doutorado. McGill University - Department of Italian Studies, Montréal, Canadá, 1999.

MARINO, Andrea (Org.). Lezione sul Novecento: storia, teoria e analisi letteraria. Milano: Vita e Pensiero (Università Cattolica del Sacro Cuore), 1990.

MARTINI, Plinio. Il fondo del sacco. 22 ed. Bellinzona: Casagrande, 2005.

MONTALE, Eugenio. Sulla poesia. Milano: Mondadori, 1997.

OLIVIERI, Ugo M. (Intro. e Org.). Un canone per il terzo millennio. Milano: Mondadori, 2001.

PAPA, Emilio R. Storia della Svizzera: dall'antichità ad oggi il mito del federalismo. Milãano: Tascabili Bompiani, 2004. 
RADIOTELEVISIONE SVIZZERA DI LINGUA ITALIANA. Emissora educativa da Confederação Suíça que transmite programação regional em língua italiana. Disponível em: $<$ http://www.rtsi.ch/scrittori/scrittore.cfm?IDc=624>. Acesso em: 30 out. 2005.

RISORCE IDRICHE. Berna: Presenza Svizzera, 2007. Publicação oficial da Confederação Suíça Disponível em: <http://www.swissworld.org/it/geografia/fiumi_e_laghi/risorse_idriche >. Acesso em: 17 fev. 2008.

SEGRE, Cesare. La letteratura italiana del Novecento. Bari: Laterza, 2004.

STORIA DI MENDRISIO. Mendrisio: Prefeitura, 2008. Publicação oficial do município. Disponível em: < http://www.mendrisio.ch/STORIA/storia1.htm>. Acesso em: 1 mar. 2008.

VALETTE, Bernard. Il romanzo: introduzione ai metodi e alle techniche moderne di annalisi letteraria. Roma: Armando, 1997.

VAN DE WALLE, Francine. Migration and fertility in Ticino. Population studies, Londres, v. 29 , no. 3 , p. 447-462, nov. 1975. 